\title{
The Role of Androgen Receptor and microRNA Interactions in Androgen-Dependent Diseases
}

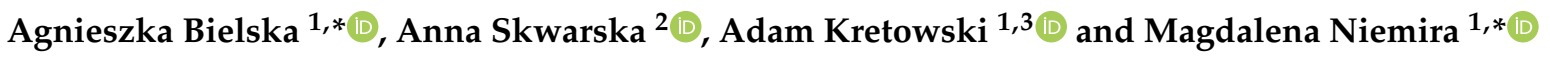 \\ 1 Clinical Research Centre, Medical University of Bialystok, 15-276 Bialystok, Poland; adamkretowski@wp.pl \\ 2 Department of Leukemia, Anderson Cancer Center, The University of Texas M.D., Houston, TX 77030, USA; \\ askwarska@mdanderson.org \\ 3 Department of Endocrinology, Diabetology and Internal Medicine, Medical University of Bialystok, \\ 15-276 Bialystok, Poland \\ * Correspondence: agnieszka.bielska@umb.edu.pl (A.B.); magdalena.niemira@umb.edu.pl (M.N.); \\ Tel.: +48-85-746-88-93 (A.B. \& M.N.)
}

Citation: Bielska, A.; Skwarska, A.; Kretowski, A.; Niemira, M. The Role of Androgen Receptor and microRNA Interactions in AndrogenDependent Diseases. Int. J. Mol. Sci. 2022, 23, 1553. https://doi.org/ $10.3390 /$ ijms 23031553

Academic Editor: Hiroshi Miyamoto

Received: 28 December 2021

Accepted: 25 January 2022

Published: 28 January 2022

Publisher's Note: MDPI stays neutral with regard to jurisdictional claims in published maps and institutional affiliations.

Copyright: (C) 2022 by the authors. Licensee MDPI, Basel, Switzerland. This article is an open access article distributed under the terms and conditions of the Creative Commons Attribution (CC BY) license (https:// creativecommons.org/licenses/by/ $4.0 /)$.

\begin{abstract}
The androgen receptor (AR) is a member of the steroid hormone receptor family of nuclear transcription factors. It is present in the primary/secondary sexual organs, kidneys, skeletal muscles, adrenal glands, skin, nervous system, and breast. Abnormal AR functioning has been identified in numerous diseases, specifically in prostate cancer (PCa). Interestingly, recent studies have indicated a relationship between the AR and microRNA (miRNA) crosstalk and cancer progression. MiRNAs are small, endogenous, non-coding molecules that are involved in crucial cellular processes, such as proliferation, apoptosis, or differentiation. On the one hand, AR may be responsible for the downregulation or upregulation of specific miRNA, while on the other hand, AR is often a target of miRNAs due to their regulatory function on $A R$ gene expression. A deeper understanding of the AR-miRNA interactions may contribute to the development of better diagnostic tools as well as to providing new therapeutic approaches. While most studies usually focus on the role of miRNAs and AR in PCa, in this review, we go beyond PCa and provide insight into the most recent discoveries about the interplay between AR and miRNAs, as well as about other AR-associated and AR-independent diseases.
\end{abstract}

Keywords: microRNA; androgen receptor; cancer; prostate cancer; breast cancer

\section{Introduction}

The androgen receptor (AR), together with the estrogen, progesterone, and glucocorticoid receptors, belongs to the steroid hormone receptor family, which acts as a liganddependent transcription factor. The $A R$ gene is a single gene that is $\sim 90 \mathrm{kbp}$ in size and located on the X-chromosome at Xq11-12 [1]. The AR is mainly present in the primary/secondary sexual organs, but is also present in the kidneys, skeletal muscles, adrenal glands, skin, nervous system, and breast [2-4]. The AR ligands, testosterone and its metabolite $5 \alpha$-dihydrotestosterone, are the most active androgen hormones and are responsible for various physiological effects on the reproductive and non-reproductive systems [5]. The circulating androgens bind to the androgen receptor that is located in the cytoplasm, which is associated with heat shock proteins (HSP) and other chaperons, which, in turn, initiates the transport of the AR dimers to the nucleus. There, AR activates or represses its respective target genes, regulating mRNA expression [6,7]. Abnormal AR functioning has been identified in numerous diseases, such as prostatic hyperplasia, prostate cancer, androgen insensitivity syndrome, hypogonadism, or spinal bulbar muscular atrophy [8]. It is therefore of critical importance to understand the molecular mechanisms governing AR activity and regulation in these pathological states. Particularly, in many AR-associated disease entities, the role of AR and its interaction with microRNA (miRNA) is still poorly described and is rarely investigated. However, most recent studies provide new evidence 
for AR-miRNA crosstalk, even in diseases such as lung cancer, liver cancer, and renal cancer, among others. In this review, we focused on the role of AR-miRNA interactions in the progression of various diseases.

\section{MiRNA}

MiRNAs are small (about 17-25 nucleotides in length), non-coding, single-stranded, endogenous molecules that play an important role in the regulation of post-transcriptional gene expression by interacting with the $3^{\prime}$ untranslated region ( $3^{\prime} \mathrm{UTR}$ ) of its target messenger RNA (mRNA) [9,10]. The complementary degree between the miRNA sequence and its target mRNA determines the regulatory effect of miRNA [11]. The association of miRNA with its target mRNA can result in mRNA cleavage, translational repression, or mRNA deadenylation [12,13]. In rare cases, miRNA can activate mRNA translation and can increase target protein levels [14]. A single miRNA can target and regulate several different genes, and a single gene can be regulated by many miRNAs, creating a complex network of interactions [15]. More than 50\% of protein-coding genes are believed to be regulated by miRNAs [16]. MiRNAs play a fundamental role in a large number of key processes, such as development, proliferation, apoptosis, metabolism, differentiation, inflammation, metastasis, angiogenesis, and tumorigenesis [10,17-19]. By 2002, it had already been shown that miRNAs are involved in cancer [20]. In recent years, miRNAs have become useful biomarkers for the diagnosis, prognosis, and therapy strategies in not only many types of cancers, such as breast, prostate, and lung cancer or melanoma, but also in metabolic, cardiovascular, and neuronal diseases [21-24]. MiRNAs can play a role as oncogenes (oncomiRs) or as suppressors of oncogenic transformation [23]. OncomiRs are frequently upregulated in cancer, and can promote tumour development by inhibiting the tumour suppressor gene, hence stimulating tumorigenesis. In contrast, tumour suppressor miRNAs are frequently downregulated in cancer and act by inhibiting oncogenes, repressing tumour progression $[25,26]$. Therefore, the inhibition of oncomiRs and the overexpression of tumour suppressor miRNAs may be a very promising strategy for targeted cancer therapies.

Most miRNA genes are transcribed by RNA polymerase II in the nucleus as primary RNA (pri-miRNAs) (Figure 1). To form a precursor of miRNAs (pre-miRNAs), the stemloop structure of a pri-miRNA is cleaved by the enzyme Drosha. The pre-miRNA, which is built from $\sim 70$ nucleotides, is subsequently exported to the cytoplasm by the Exportin- 5 protein. Once in the cytoplasm, the pre-miRNA is cleaved by the enzyme Dicer, which splits it into double-stranded miRNA. Finally, one of the strands of miRNA is removed, and another is bound to the AGO2 protein, which is a member of RISC (RNA-included silencing complex). This complex can target the $3^{\prime}$ UTR region of the mRNA, which results in mRNA deadenylation, translational repression, or mRNA cleavage $[25,27,28]$.

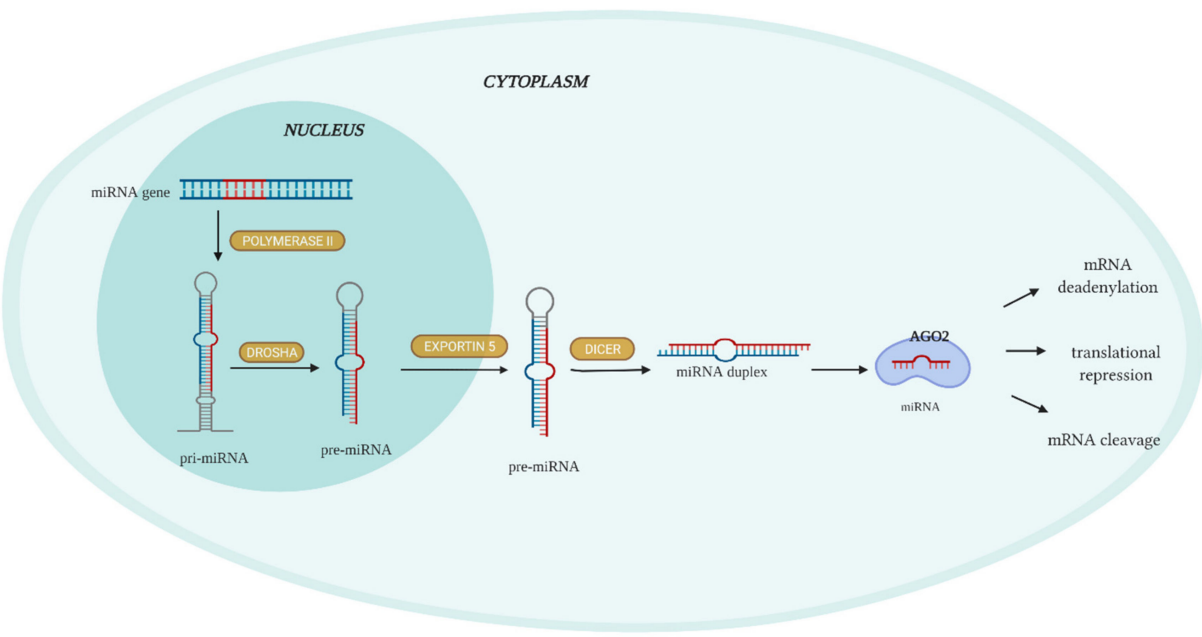

Figure 1. MicroRNA (miRNA) biosynthesis and functions. MiRNA gene is transcribed by polymerase II to primary RNA (pri-miRNA). The ribonuclease Drosha is involved in the process of changing pri- 
miRNA into pre-miRNA. Afterwards, pre-miRNA is transported via Exportin-5 from the nucleus to the cytoplasm. Dicer is an endonuclease that splits pre-miRNAs into short miRNA duplexes. The unknown helicase participates in the splitting of the miRNA duplexes. The mature miRNA binds to the Argonaute (Ago) protein, creating a complex that targets the $3^{\prime}$ UTR region of targeted mRNA. Illustration created using BioRender.com (access date: 28 December 2021).

\section{3. miRNA and AR}

Most recent research emphasizes the importance of the interactions between miRNAs. AR expression can be regulated by different miRNAs directly or indirectly by affecting the expression of co-regulators (co-activators and co-repressors), which can shape AR functions [29-32] (Figure 2).
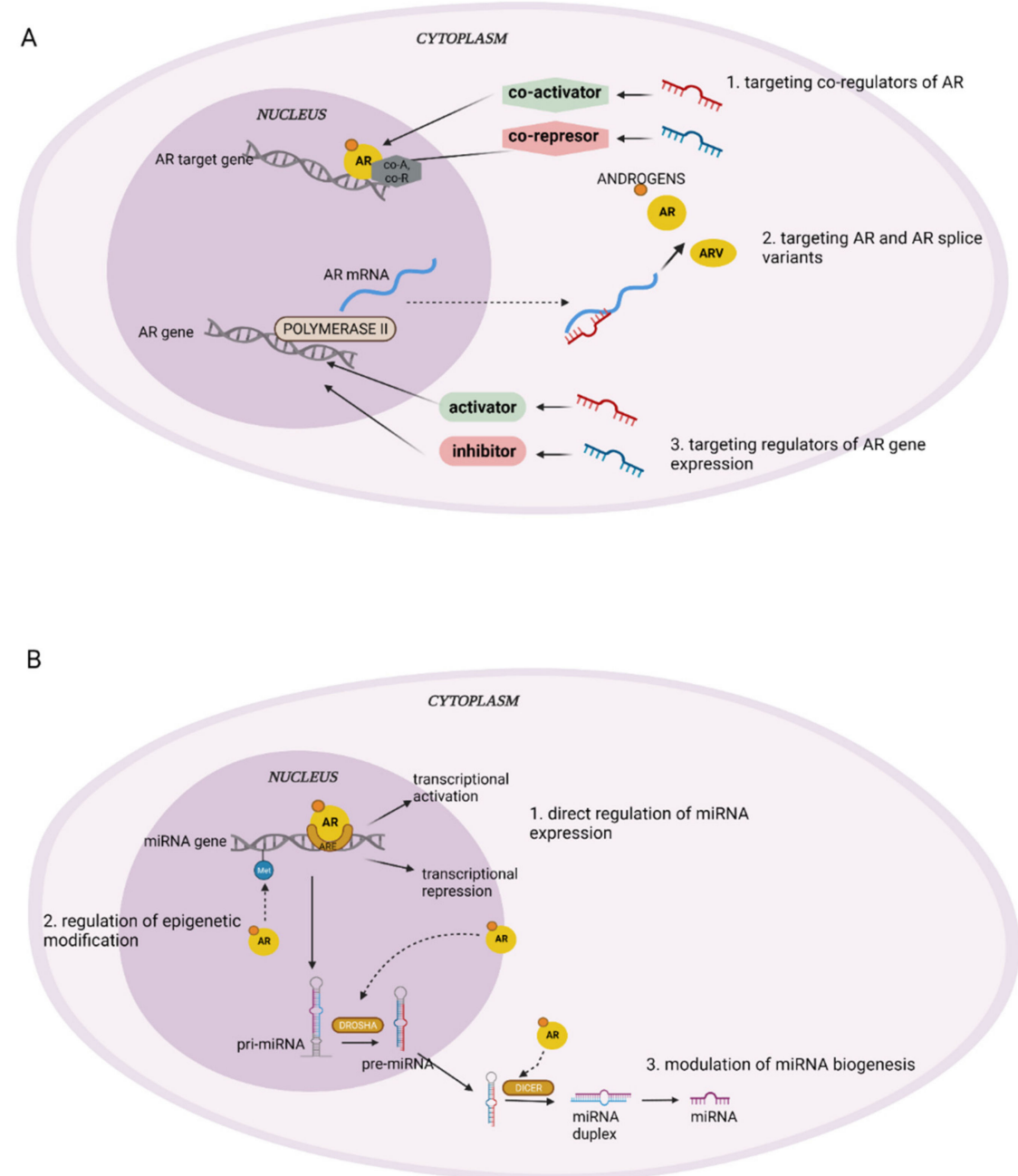

Figure 2. Main mechanisms of AR regulation by miRNA (A) and miRNA regulation by AR (B). Illustration created using BioRender.com (access date: 28 December 2021).

For example, prohibitin is considered to be a corepressor of AR. Fletcher et al. showed that prohibitin is targeted by miR-27a, which leads to the increased expression of AR target genes and PCa cell growth [31]. Another study showed that miR-137 targets AR co-activators, including an extended network of transcriptional coregulators, such as Lysine Demethylase 1A (KDM1A), Mediator Complex Subunit 1 (MED1), or Nuclear Receptor Coactivator 2 (TIF2) [32]. In PCa cell lines, miR-17-5p indirectly modulates the transcriptional activity of AR by targeting the p300/CBP-associated factor (PCAF) [31]. In addition, miRNAs can target the factors that regulate AR gene expression. MiR-let-7c 
indirectly represses AR activity by targeting the oncogenic transcription factor c-Myc [33]. The second regulatory mechanism of AR expression involves the direct targeting of AR or the AR splice variants (ARVs) by miRNAs [34]. For example, miR488* directly affects AR signalling by targeting the $3^{\prime}$ UTR of AR and downregulates AR protein expression in PCa cells, which leads to apoptotic cell death [35].

On the other hand, under various conditions, the androgens and AR may be responsible for the downregulation or upregulation of specific miRNAs (Figure 2). AR can directly regulate miRNAs by binding to specific DNA sequences, termed androgen response elements (AREs), in the regulatory region of the target genes. AREs are dihexameric motifs that are located in the enhancers and promoters of their target genes. As a result, transcriptional activation or, rarely, repression occurs. Wang et al. showed that AR upregulates miR-4496 expression by directly binding to the AREs of the miR-4496 promoter. Subsequently, the miR-4496 decreases the expression of $\beta$-catenin by directly targeting the $3^{\prime}$ UTR of the $\beta$-catenin-mRNA [36]. Another way that miRNA can be regulated by AR is through the indirect regulation of epigenetic modifications. In PCa cells, AR associates with KDM1A (lysine-specific demethylase 1), which enables the removal of repressive methyl marks in AR-targeted genes [37]. This also modulates the methylation of the promoter elements of AR-upregulated miRNAs (miR-22 and miR-29a) [38]. Finally, AR may modulate the biogenesis of miRNA. It has been shown that in PCa cells, AR can regulate the expression of the crucial enzymes that are required for miRNA biogenesis, such as Dicer and Drosha $[31,39]$.

\section{4. miRNA and AR in Various Diseases}

While AR is commonly associated with prostate cancer, recent studies indicate that not only AR, but also the AR-miRNA interactions, play a key role in cancers, such as liver cancer, genitourinary cancer, and pancreatic cancer, in other diseases, such as PCO and cardiovascular disorders, and in normal processes, such as adipogenesis and placenta development. Table 1 provides insight into the novel findings regarding the AR-miRNA crosstalk that takes place during these processes. 
Table 1. The main new findings about miRNA-AR relation in different conditions in humans.

\begin{tabular}{|c|c|c|c|c|}
\hline Condition & miRNA & Significant Findings and Implications Concerning AR-miRNA Interactions & Year of Publication & Reference \\
\hline \multirow{7}{*}{ Breast cancer } & miR-185, miR-205, miR-21 & $\begin{array}{c}\text { Disturbance of AR, miR-205, miR-185, and miR-21 expression may be the marker for the presence of } \\
\text { metastases depends on the tumour subtype. }\end{array}$ & 2020 & [40] \\
\hline & miR-21 & AR downregulates miR-21 expression & 2016 & [41] \\
\hline & miR-100, miR-125 & AR regulates the extracellular release of MMP13 via the regulation of miR-100 and miR-125 & 2017 & [42] \\
\hline & \multirow{2}{*}{ miR-328-3p } & DHT regulates miR-328-3p expression via AR & 2018 & [43] \\
\hline & & DHT controls chemo-response independently of ABCG2 and miR-328-3p & 2021 & [44] \\
\hline & miR-9-5p & miR-9-5p acts as a tumour suppressor and downregulates AR & 2020 & [45] \\
\hline & $\begin{array}{l}153 \text { DE miRNAs in AR- positive BC including miR-933, } \\
\text { miR-5793, miR-4792 }\end{array}$ & miRNAs promote $A R$-mediated signalling $B C$ progression & 2017 & [46] \\
\hline \multirow{5}{*}{ Prostate cancer } & $\mathrm{miR}-760$ & Downregulation of miR-760 promotes cancer cell growth by regulating IL- 6 & 2021 & [47] \\
\hline & $\begin{array}{l}\text { miR-216a-5p, miR-183-5p, miR-206, miR-3160-5p, } \\
\text { miRNA-204-5p }\end{array}$ & $\begin{array}{l}\text { Target prediction analysis for } 5 \text { circRNAs related to the AR signalling pathway showed } \\
\text { circRNA-miRNA regulatory network with more than } 200 \text { interactions }\end{array}$ & 2021 & [48] \\
\hline & $\begin{array}{c}\text { miR-1-3p, miR-125b-5p, miR-145-5p, miR-182-5p, } \\
\text { miR-198, miR-24-3p, miR-34a-5p, miR-22-3p, } \\
\text { miR-499a-5p }\end{array}$ & $\begin{array}{l}\text { miR-145-5p/NDRG2/AR and miR-145-5p/KLF5/AR axis were found to be potential mechanisms in } \\
\text { PCa development }\end{array}$ & 2021 & [49] \\
\hline & miR-210-3p, miR-23c, miR-592, miR-93-5 & $\begin{array}{l}\text { miR-210-3p, miR-23c, miR-592, and miR-93-5 as a potential diagnostic and aggressiveness biomarkers } \\
\text { for PCa }\end{array}$ & 2021 & [50] \\
\hline & miR-3195, miR-3687, miR-4417 & Upregulation of miR-3195, miR-3687, and miR-4417 in PCa & 2021 & [51] \\
\hline \multirow{6}{*}{ Renal cell carcinoma } & \multirow[t]{2}{*}{ miR-185-5p } & $\begin{array}{l}\text { AR elevates the expression of miR-185-5p, which suppresses VEGF-C and increases } \\
\text { HIF2 } \alpha / \text { VEGF-A expression }\end{array}$ & 2017 & [53] \\
\hline & & AR affects RCC metastasis via regulation of miR-185-5p & 2020 & [54] \\
\hline & miR-34a-5p & AR increases proliferation of RCC cells through regulation of ASS1P3/miR-34a-5p/ASS1 signalling & 2019 & [55] \\
\hline & miR-145 & AR negatively regulates miR-145, which enhances RCC cell invasion and proliferation & 2015 & [56] \\
\hline & miR-195-5p, 29a-3p, 29c-3p & $\begin{array}{l}\text { AR promotes RCC cell migration and invasion by regulating } \\
\text { circHIAT1/miR-195-5p/29a-3p/29c-3p/CDC42 signals }\end{array}$ & 2017 & [57] \\
\hline & miR-143-3p & IncRNA-SARCC suppresses RCC progression via altering AR/miRNA-143-3p signalling & 2017 & [58] \\
\hline \multirow[t]{2}{*}{ Bladder cancer } & $\operatorname{miR}-525-5 p$ & $\begin{array}{c}\text { AR binds to different AREs on the miR-525-5p promoter region and increases metastasis in } \\
\text { bladder cancer }\end{array}$ & 2020 & [59] \\
\hline & miR-124 & XIST inhibits miR-124 expression; miR-124 regulates AR expression & 2017 & [60] \\
\hline Urothelial carcinoma & miR-27a, miR-125b, miR-145, miR-200b, miR200c & AR promote expansion of CSC & 2016 & [61] \\
\hline
\end{tabular}


Table 1. Cont.

\begin{tabular}{|c|c|c|c|c|}
\hline Condition & miRNA & Significant Findings and Implications Concerning AR-miRNA Interactions & Year of Publication & Reference \\
\hline \multirow{3}{*}{ Liver cancer } & miR-216a, miR-224 & miR-216a and miR-224 are upregulated in HCC tissues & 2012 & [62] \\
\hline & miR-532-3p & $\begin{array}{l}\text { AR/circ-LNPEP/miR-532-3p/RAB9A signalling axis may be committed to hypoxia-induced cell } \\
\text { invasion of HCC cells }\end{array}$ & 2021 & [63] \\
\hline & miR-6511a-5p, miR-4667-5p & $\begin{array}{l}\text { Competing endogenous RNA network analysis indicates that some miRNAs and circRNAs are } \\
\text { connected to AR in HCC }\end{array}$ & 2021 & [64] \\
\hline Thyroid cancer & miR-124a & $\begin{array}{l}\text { AR is a target for miR-124a; miR-124a determines the expression of AR gene in human thyroid } \\
\text { cancer tissues }\end{array}$ & 2012 & [65] \\
\hline Head and neck cancer & 53 DE miRNAs & A total of 16 miRNAs might be involved in the regulation of AR in head and neck cancer & 2017 & [66] \\
\hline \multirow{2}{*}{ Pancreatic cancer } & $\begin{array}{l}232 \text { DE miRNAs including the miR-200 family and } \\
\text { miR-192/215 }\end{array}$ & AR is targeted by miR-376b & 2014 & [67] \\
\hline & 494 miRNAs & PPI network analysis of target genes for miR-376b and miR-376c showed AR as a hub gene & 2018 & [68] \\
\hline Lung cancer & 59 DE miRNAs & Transcriptional factor regulatory network showed miR-657 as regulator of AR expression & 2017 & [69] \\
\hline IPAH, CTEPH, APTE & $\begin{array}{l}21 \text { DE miRNAs including let-7i-5p, miR-320a } \\
\text { miR-320b-1, miR-320b-2, miR-1291 }\end{array}$ & AR is a target gene for let-7i-5p and miR-320a & 2021 & [70] \\
\hline СТЕРН & 46 DE miRNAs including miR-3148 & $\mathrm{AR}$ is a target for miR-3148 & 2017 & [71] \\
\hline Ovarian cancer & $\begin{array}{l}137 \text { DE miRNAs including miR-93-5p, miR-19a-3p, } \\
\text { miR-22-3p, miR-362-5p, miR-210-3p }\end{array}$ & Most of tested miRNA target genes were connected to hypoxia and androgen pathways & 2019 & [72] \\
\hline \multirow[t]{2}{*}{$\mathrm{PCO}$} & $\begin{array}{l}38 \text { DE miRNAs included miR-30c-5p, miR-34c-5p, } \\
\text { miR-142-3p, miR-199a-3p, miR-224-3p, miR-548d-3p, } \\
\text { miR-597-5p, miR-598-3p, miR-1468-5p, miR-107, } \\
\text { miR-151a-3p, miR-199a-5p, miR-1539 }\end{array}$ & $\begin{array}{l}\text { AR is a target of miR-30c-5p, miR-199-5p, and miR-597; other miRNAs possibly involved } \\
\text { in AR signalling }\end{array}$ & 2018 & [73] \\
\hline & miR-1260a, miR-18b-5p, miR-424-5p, and miR-let-7b-3p & miR-1260a corelate with androgen levels & 2020 & [74] \\
\hline $\begin{array}{l}\text { Early-onset preeclampsia } \\
\text { placentas }\end{array}$ & miR-22 & Production of androgen and estrogen is modulated by miR-22 & 2017 & [75] \\
\hline Placenta development & let-7c & LIN28 regulates AR expression via let-7c & 2019 & [76] \\
\hline \multirow{2}{*}{ Adipogenesis } & miR-130a, miR-301 & $\begin{array}{l}\text { miR-130a is upregulated under androgen stimulation in the adipogenesis; } A R \text { is a target } \\
\text { gene for miR-130a }\end{array}$ & 2020 & [77] \\
\hline & $\operatorname{miR}-375$ & $\begin{array}{c}\text { miR-375 is upregulated during adipogenic differentiation and is downregulated after } \\
\text { androgen treatment }\end{array}$ & 2015 & [78] \\
\hline Insulin resistance & miRNA profile & $\begin{array}{l}\text { PPI network indicated that AR was regulated by } 96 \text { different miRNAs in subcutaneous } \\
\text { insulin resistance }\end{array}$ & 2019 & [79] \\
\hline
\end{tabular}

ABCG2: ATP-binding cassette subfamily G member 2; APTE: acute pulmonary embolism; BC: breast cancer; AR: androgen receptor; ARE: androgen response element; circRNA: circular RNA;; CSC: cancer stem cells; CTEPH: chronic thromboembolic pulmonary hypertension; DE: differentially expressed; DHT: dihydrotestosterone; HCC: hepatocellular carcinoma HIF2 $\alpha$ : hypoxia-inducible factor 2 alfa; IL-6: interleukin 6; IPAH: idiopathic pulmonary artery hypertension; MMP13: metalloprotease-13; PCa: prostate cancer; PPI: protein-protein interaction;f;on; RCC: renal cell carcinoma; VEGF-A: vascular endothelial growth factor A; VEGF-C: vascular endothelial growth factor C. 
Table 2 presents the main oncomiRs and tumour suppressor miRNAs connected with androgen receptors in the different types of cancer discussed in this paper.

Table 2. Key oncomiRs and suppressor miRNAs connected with androgen receptors in different types of cancer.

\begin{tabular}{|c|c|c|c|}
\hline Cancer Type & miRNA & miRNA Type & Reference \\
\hline \multirow{5}{*}{ Breast cancer } & miR-185 & suppresor & [40] \\
\hline & $\operatorname{miR}-21$ & oncomiR & [41] \\
\hline & miR-100 & suppresor & [80] \\
\hline & $\operatorname{miR}-328-3 p$ & suppresor & [44] \\
\hline & $\operatorname{miR}-9-5 p$ & suppresor & {$[45]$} \\
\hline \multirow{5}{*}{ Prostate cancer } & miR-760 & suppresor & [47] \\
\hline & miR-204-5p & suppresor & [48] \\
\hline & miR-34a-5p, miR-145-5p & suppresor & [49] \\
\hline & miR-93-5 & oncomiR & {$[50,81]$} \\
\hline & miR-1205 & suppresor & {$[52]$} \\
\hline \multirow{5}{*}{ Renal cell carcinoma } & $\operatorname{miR}-185-5 p$ & oncomiR & [53] \\
\hline & $\operatorname{miR}-34 a-5 p$ & suppresor/oncomiR & {$[55]$} \\
\hline & miR-145 & suppresor & {$[56,82]$} \\
\hline & miR-195-5p, 29a-3p, 29c-3p & suppresor & {$[57]$} \\
\hline & miR-143-3p & suppresor & [58] \\
\hline \multirow{2}{*}{ Bladder cancer } & miR-525-5p & suppresor & [59] \\
\hline & miR-124 & suppresor & {$[60,83]$} \\
\hline \multirow{2}{*}{ Urothelial carcinoma } & miR-27a, miR-125b & oncomiR & {$[61]$} \\
\hline & miR-145, miR-200b, miR-200c & suppresor & [61] \\
\hline \multirow{2}{*}{ Liver cancer } & miR-216a & oncomiR & {$[62]$} \\
\hline & miR-532-3p & oncomiR & {$[63,84]$} \\
\hline Thyroid cancer & miR-124a & suppresor & {$[65,85]$} \\
\hline Head and neck cancer & miR-100 & suppresor & {$[66,86]$} \\
\hline Pancreatic cancer & miR-200 family & suppresor & {$[67,87]$} \\
\hline Lung cancer & miR-1197 & oncomiR & [88] \\
\hline Ovarian cancer & miR-93-5p & suppresor & {$[72,89]$} \\
\hline
\end{tabular}

\subsection{AR and miRNA in Breast Cancer}

In general, androgens are considered male hormones, but they are also present in females. Androgens play a crucial role in female development and physiology [90,91], and a vast majority of breast cancers (BC) are positive for AR $[45,92,93]$. An increasing number of studies indicate a link between miRNA and AR in BC development and metastasis [94,95]. In many cases of triple-negative breast cancer (TNBC), the tumour cells show AR expression. It is possible that AR promotes the progression of this type of cancer through controlling the expression of miRNAs that are crucial for BC development, such as miR-125b, miR-21, and let-7a. These miRNAs target particular mRNAs that affect the protein expression involved in BC development, such as the transmembrane glycoprotein cluster of differentiation 44 (CD44), estrogen receptor (ER), progesterone receptor (PR), and receptor tyrosine-protein kinase erbB-2 (HER-2) [96]. In a recent study, Kalinina et al. showed that the changes in expression levels of AR, miR-185, miR-205, and miR-21 vary in specific BC subtypes [40]. MiR-185 and miR-205 were previously described as miRNAs that are able to directly target AR expression [97,98]. Interestingly, AR regulates the transcription of miR-21, which promotes PCa growth [99]. Huang et al. also confirmed a link between a miR-185-5p and AR in clear cell renal cell carcinoma (ccRCC). AR elevates the expression of miR-185-5p, which suppresses VEGF-C and increases HIF2 $\alpha$ /VEGF-A expression [53]. In contrast, in breast cancer, androgens have been reported to act as negative modulators of the miR-21, which 
results in a reduction in $\mathrm{BC}$ cells proliferation. In such cases, AR acts as a transcriptional repressor of miR-21 expression [41]. MiR-21 often plays the role of the main onco-miRNA in carcinogenesis, and its expression is consistently high in hormone-dependent cancers, including PCa and BC [100,101]. MiR-206 is also regulated by hormones in both BC and PCa, and may act as a tumour suppressor as well as an oncogene [102,103]. Ahram et al. showed that AR may regulate the extracellular release of metalloprotease-13 (MMP13) in the $\mathrm{BC}$ cell lines by controlling miRNA expression. In response to the AR agonist CI4AS-1, the expression of miR-100 and miR-125 was significantly reduced in MDA-MB-453 breast cancer cells, leading to the increased expression of miR-100 and miR-125 target metalloprotease-13 (MMP13) [42]. MiR-328-3p can mediate the AR regulation of BC, and AR controls the expression of CD44 via miRNA-dependent and independent mechanisms in BC cells. In TNBC, exposure to DHT significantly upregulated the miR-328-3p level, leading to decreased expression of the miR-328-3p target CD44 and the subsequent reduction in cell adhesion and migration [43]. In contrast, Al-Momany et al. recently showed that DHT was able to regulate the chemo-response in TNBC through a mechanism that was independent of miR-328-3p and ABCG2 [44]. Studies report that miR-9-5p acts as both an onco-miR and a tumour suppressor, and its role is still debated. However, a recent work by Li et al. suggested that the miR-9 level, and its role in BC, depends on the stage of the disease. MiR-9 may inhibit the occurrence of BC in the early stages of the disease, and may also act as an onco-miR in metastatic BC with a higher malignancy [104]. Bandini et al. suggested that miR-9-5p potentially targets $A R$ and that it may play a key role as a regulator of the AR pathways in BC cell lines. MiR-9-5p was downregulated in the BC cell lines (T-47D, MDA-MB-453, and MCF-7). Transfection with miR-9-5p resulted in the significant downregulation of $A R$, both at the mRNA and protein levels. Interestingly, miR-9-5p is upregulated after androgen stimulation, which indicates a feedback loop between miR-9-5p and AR [45]. MiR-18a belongs to a miR-17-92a cluster and is significantly upregulated in BC $[105,106]$. Although the miR-17-92a cluster is upregulated by the AR, its exact role in $\mathrm{BC}$ progression remains unknown. As shown by Ottman et al., cluster miR-1792a may induce prostate cell sensitivity to drugs (docetaxel, bicalutamide) and the AKT inhibitor MK-2206 2HCl. The inhibition of this cluster seems to be a promising therapeutic strategy [107]. Whether similar dependence also occurs in BC requires further investigation. Shi et al. have provided additional insight into the interactions of miRNAs and AR in BC. A comparison of the level of miRNA expression between AR-positive and AR-negative BC cell lines uncovered more than 150 differentially expressed miRNAs in AR-positive BC cells. The most significantly upregulated miRNAs were miR-933 and miR-5793, and the most downregulated was miR-4792. Many of the upregulated miRNAs were connected to BC cell proliferation, invasion, and drug resistance. Furthermore, networks of connection for predicted target genes showed their involvement in VEGF (vascular endothelial growth factor) and in the mammalian target of rapamycin (mTOR) signalling pathways, which are significant in BC tumorigenesis [46].

\subsection{AR and miRNA in Prostate Cancer}

The androgen receptor plays an important role in both the normal development of the prostate gland and its abnormal growth. The roles of AR in both miRNA regulation and miRNA-mediated regulation have mostly been extensively studied and documented in PCa studies. In 2007, Porkka et al. showed that androgens may regulate the expression of specific miRNAs in PCa cell lines [108]. Later, Epis et al. demonstrated that AR signalling was indirectly regulated by miR-331-3p in LNCaP cells [109]. In their studies, Stope et al. have shown that tumour suppressor miR-1 and small heat shock protein beta-1 (HSPB1) are involved in the development of PCa. The previously mentioned miR-21 is not only important in BC but also in PCa progression. Ribas and colleagues indicated that AR binds to miR-21 promoter and increases its expression, suggesting direct transcriptional regulation in PCa cell lines [99]. In PCa cells, HSPB1 reduces the expression of miR-1 and subsequently restores the oncogenic signalling pathways of AR. Interestingly, miR- 
1 overexpression significantly decreased PCa cell proliferation [110-112]. MiR-3162-5p has been shown to affect the proliferation and migration of PCa cells, while regulating kallikrein-related peptidase $(K L K)$ and AR, by directly targeting their expression [113]. In contrast, AR may target AR/miR-4496/ $\beta$-catenin signalling by regulating the expression of miR-4496 via direct binding to ARE sequences within the miR-4496 promoter [36]. More recently, miR-760 showed lowered expression in PCa tissues compared to in normal tissues. It was proven that androgens inhibit the expression of this miRNA in the LNCaP and 22rv1 cell lines. The downregulation of miR-760 promoted proliferation and growth in the PCa cell lines. Furthermore, miR-760 bound to the 3'UTR of interleukin-6 (IL-6) and inhibited its expression. This study demonstrated that androgens downregulate miR-760 to promote the growth of PCa cells by regulating IL-6 [47]. Another interesting study identified the key miRNAs in PCa using bioinformatic analysis [49]. The authors integrated gene expression and miRNA-mRNA association data to construct networks of hub miRNAs, and proposed candidate miRNA molecules that were specific to PCa occurrence and progression. Seven identified miRNAs (miR-1-3p, miR-125b-5p, miR-145-5p, miR-182-5p, miR-198, miR-24-3p, and miR-34a-5p) have been previously described to be involved in PCa and AR functioning, and two miRNAs, miR-22-3p and miR-499a-5p, have been proposed as candidates for new PCa biomarkers [114-117]. In addition, using bioinformatic and molecular analysis, Martinez-Gonzalez et al. indicated that miR-210-3p, miR-23c, miR-93-5p, and miR-592 were further potential non-invasive biomarkers for PCa. Interestingly, the implication of miR-23c in PCa has been shown for the first time [50]. Castration-resistant prostate cancer (CRPC) is a type of PCa that progresses despite medical or surgical castration [118]. In a profiling study, Rönnau et al. demonstrated several novel miRNAs that were significantly dysregulated in CRPC compared to in primary PCa tissue. MiR-3195, miR-3687, and miR4417 were upregulated, while miR-205 and miR-92b were downregulated, in CRPC [51]. Interestingly, cell culture experiments showed a reduction in the expression levels of miR3687 and miR-4417 in androgen-treated VCaP and LNCaP cell lines. MiR-1205 showed lowered expression in the PCa cell lines and tissues when compared to normal prostate epithelial cells and normal prostatic tissue. Furthermore, mice with CRPC treated with the miR-1205 synthetic analog (NB1205) showed smaller volumes of prostate tumour, which suggests that miR-1205 may have tumour suppressive properties in PCa. The FRY-like transcription coactivator $(F R Y L)$ is a direct molecular target for miR-1205, and is overexpressed in PCa tissue and in PCa cell line models. The overexpression of miR-1205 induces FRYL protein inhibition [52].

Circular RNA (circRNA) is an endogenous, non-coding, single-stranded RNA with a covalently closed loop with no $5^{\prime}$ cap or $3^{\prime}$ poly(A) tail $[119,120]$. Most recent studies indicate that the functioning of miRNA can be also regulated by circRNAs, which act as sponges and compete with mRNAs to bind to miRNAs [121,122]. Zhang et al., identified five circRNAs that were related to AR signalling and PCa progression [48]. Bioinformatic analysis proposed a network of over 200 possible interactions for these circRNAs with miRNAs, using the miRDB database for miRNA target prediction and functional annotations. MiR-216a-5p, miR-183-5p, and miR-206 were previously reported as being important components in PCa $[123,124]$.

\subsection{AR and miRNA in Other Genitourinary System Diseases}

MiRNA expression is often altered not only in PCa, but also in other genitourinary cancers $[125,126]$. Furthermore, in these types of cancers, abnormal miRNA interactions with AR have also been described. Renal cell carcinoma (RCC) is the most common kidney cancer and is formed from renal tubular epithelial cells [127,128]. In 2017, Huang et al. indicated a unique mechanism by which AR increased or decreased clear cell RCC (ccRCC) metastasis. The majority of ccRCC subtypes lack the VHL gene (von Hippel-Lindau), which leads to the stabilization of hypoxia-inducible factors (HIF) and increased expression of vascular endothelium growth factors (VEGFs). Interestingly, AR-positive ccRCC cells preferably metastasize to the lung rather than to the lymph nodes. Moreover, AR may 
elevate the expression of miR-185-5p through binding to its AREs, which subsequently suppresses the expression of VEGF-C (vascular endothelial growth factor $\mathrm{C}$ ) and increases the levels of HIF2 $\alpha / V E G F-A$ (hypoxia-inducible factor 2 alfa/vascular endothelial growth factor A) [53]. In addition, AR has been shown to affect the metastasis of $V H L$ wild-type clear cell RCC [54]. Depending on oxygen availability, AR transcriptionally suppresses or promotes miR-185-5p expression, resulting in changes in the VEGF-C and HIF2 $\alpha / V E G F-A$ levels. A study by Wang et al. showed that AR may also increase the proliferation of RCC cells independently of the VHL status. Moreover, the authors found that the growth of RCC cells was promoted through the AR-dependent regulation of ASS1P3/miR-34a$5 p / A S S 1$ signalling [55]. MiR-34a-5p was previously described as a tumour suppressor in RCC $[129,130]$. AR also negatively regulates the expression of miR-145, which leads to increased RCC cell proliferation and invasion [56]. Another interesting study showing the link between AR and miRNAs in RCC, indicated that AR effects ccRCC cell migration and invasion by changing circHIAT1/miR-195-5p/29a-3p/29c-3p/CDC42 signalling [57]. The suppression of circulating RNA circHIAT1 by AR resulted in altered miR-195-5p/29a$3 p / 29 c-3 p$ expression, which increased cell division cycle 42 protein (CDC42) expression, leading to intensified cell migration and invasion. Other studies have shown that AR may directly bind to the miR-143-3p promoter and potentially suppress its expression. Correspondingly, the novel long non-coding RNA lncRNA-SARCC (lncRNA-suppressing androgen receptor in renal cell carcinoma) has been shown to inhibit the AR protein by binding to it and destabilizing it, thus increasing the miR-143-3p level in RCC. The authors also found that Sunitinib (a protein tyrosine kinase inhibitor used in patients with RCC) induces lncRNA-SARCC expression, decreasing the resistance of RCC cells to this drug. These findings provide insight into the role of lncRNA-SARCC as a suppressor of RCC progression and highlight new therapeutic strategies for RCC treatment in the context of AR-miRNA regulation [58].

In bladder cancer, Yang et al. demonstrated that AR decreased the transcription of miR-525-5p by binding to different AREs located at different positions of the miR-525-5p precursor promoter, which subsequently altered miRNA-525-5p/SLPI (secretory leukocyte peptidase inhibitor) signalling and increased cancer metastasis [59]. An important link between miRNAs and AR involving lncRNA was presented by Xiong et al. LncRNA XIST (X-inactive specific transcript) promoted bladder cancer growth invasion and migration through the direct inhibition of miR-124, which is known to block AR expression by binding to the $3^{\prime} \mathrm{UTR}$ of AR [60].

In upper urinary tract urothelial cell carcinoma (UUTUC), the presence of AR in the CSC (cancer stem cell) population increased cell clonogenicity, in vitro spheroid formation, and changed the miRNA profile. Oncomirs miR-27a and miR-125b were upregulated in the BFTC hAR cells, while the tumour suppressors miR-145, miR-200b, and miR-200c were downregulated. This indicates that, in UUTUC cells, AR may upregulate the miRNAs that promote the expansion of the CSC population, and downregulate the miRNAs that suppress CSC population expansion. Further studies are required to understand the exact mechanism by which AR modulates CSCs by regulating miRNA networks. These findings provide new insight into AR functions in UUTUC [61].

At this point, it is worth mentioning that kidney stone disease is a common urological disorder [131]. Zhu et al. indicated that the loss of AR expression in renal tubular epithelial cells inhibits intrarenal calcium oxalate crystal deposition by altering macrophage recruitment and M2 macrophages polarization. Research suggests that AR can suppress macrophage colony-stimulating factor 1 (CSF-1) expression through the upregulation of miR-185-5p [132].

\subsection{AR and miRNA in Liver Cancer}

There is an increasing amount of evidence linking the AR to liver cancer $[133,134]$. Similarly, miRNAs, such as miR-216a, miR-155, or miR-21, have been implicated in the development of liver cancer [135]. Chen et al. showed that miR-216a and miR-224 were 
significantly upregulated in hepatocellular carcinoma (HCC), starting from the early stages of carcinogenesis. Interestingly, miR-216a levels were elevated in male patients, and the ligand-stimulated activation of AR led to the increased transcription of pri-miR-216a, indicating the possible involvement of androgens in the regulation of miR-216a biogenesis. It is important to note that this effect was not observed for miR-224 [62]. Another interesting study indicated a new AR/circ-LNPEP/miR-532-3p/RAB9A (AR/circ-leucyl and cystinyl aminopeptidase/miR-532-3p/ras-related protein rab-9a) signalling axis that is involved in the hypoxia-induced invasion of HCC cells. The researchers reported that the loss of AR under hypoxia increases HCC invasion via boost circ-LNPEP expression. This circular RNA acts as a sponge for miR-532-3p and consequently enhances the expression of RAB9A. This finding may help to provide new treatment strategies for HCC patients, which may include enhancing AR expression [63].

In a more recent paper, Huang et al. described the use of multiple omics integration in HCC research. The authors used miRanda software to predict the miRNA binding sites of the circRNAs within the junction regions, and collected mRNA-miRNA interactions from the miRTarBase database. A competing endogenous RNA network was then constructed using the miRNAs and differentially expressed genes, and the circRNAs indicated that some miRNAs (miR-6511a-5p and 4667-5p), as well as certain circRNAs (hsa_circ_0002130 and hsa_circ_0008774, hsa_circ_0008774), are connected to the AR in HCC [64].

\subsection{AR and miRNA in Thyroid and Head and Neck Cancer}

Stanley et al. reported a link between miR-124a and AR in thyroid cancer. In a target prediction analysis, $A R$ was identified as a direct target of miR-124a. Experimental analysis confirmed that miR-124a determined the expression pattern of the $A R$ gene in thyroid cancer tissues. In addition, miR-124a is considered to be a potential factor underlying the gender-specific expression of AR in thyroid cancer. The expression of AR mRNA was elevated in men and lowered in women (excluding follicular thyroid carcinoma) and showed a negative correlation with miR-124a expression. Interestingly, studies on cell lines have indicated that miR-124a diminishes cell proliferation [65].

In head and neck squamous cell carcinoma, a meta-analysis of miRNA expression combined with a protein-protein interaction network analysis identified over 50 differentially expressed miRNAs, where 16 miRNAs were involved in the regulation of AR. The analysis showed that some miRNAs are tumour-suppressing and that others play oncogenic roles. The overexpression of miR-7, miR-9, miR-15, miR-18, miR-19, miR-21, miR-23, miR-24, miR-93, miR-96, miR-99, miR-130, miR-139, miR-141, miR-155, miR-181, miR-195, miR-196, miR-210, miR-211, miR-214, miR-222, miR-296, miR-302, miR-331, miR-345, and $\mathrm{miR}-424$ was associated with poor prognosis in head and neck squamous cell carcinoma. Decreased expressions of miR-17, miR-26, miR-29, miR-31, miR-34, miR-125, miR-126, miR137, miR-138, miR-143, miR-152, miR-200, miR-203, miR-205, miR-206, miR-218, miR-324, miR-363, miR-375, miR-451, miR-489, miR-491, miR-506, miR-519, miR-639, and let-7d were correlated with lower survival and metastasis [66].

\subsection{AR and miRNA in Pancreatic Cancer}

Recent works have indicated the role of AR in the development of pancreatic cancer $[136,137]$. Rare solid-pseudopapillary neoplasms of the pancreas have been shown to have upregulated Wnt/ $\beta$-catenin, Hedgehog, and AR signalling pathways, and miRNA profiling revealed that 17 miRNAs were associated with these pathways. Specifically, the AR could be targeted by miR-376b [67]. Another analysis of the miRNA profile in pancreatic cancer patients identified 10 miRNAs with the highest prognostic prediction values for pancreatic adenocarcinoma. A protein-protein interaction network analysis of the target genes for miR-376b and miR-376c indicated $A R$ as a hub gene [68]. 


\subsection{AR and miRNA in Lung Cancer}

AR was found to be expressed not only in normal tissue, but also in cancerous tissues of the lungs $[138,139]$. Correspondingly, many studies emphasize the role of miRNAs as a potential biomarker for lung cancer $[136,140]$. In addition, Bouhaddioui et al. showed that the miRNAs involved in lung development in foetal mice were androgen-dependent [137]. In an interesting study by Jin et al., the authors analysed RNA sequencing data from blood samples taken from lung cancer patients and healthy controls. They identified 59 differentially expressed miRNAs. Transcriptional factor regulatory network analysis showed that the miR-657 target WT1 (Wilms' tumour gene) and the miR-582-5p target ETV1 (ETS variant 1) regulate the $A R$ gene at the same time [69]. These studies demonstrate the need for further research on $\mathrm{AR}-\mathrm{miRNA}$ regulation in lung cancer.

\subsection{AR and miRNA in Cardiovascular Diseases}

Cardiovascular disease is still the leading cause of mortality worldwide [141]. There is substantial evidence regarding the relationships between AR and hypertension, stroke, atherosclerosis, and myocardial infarction [142]. However, knowledge of AR-miRNA interactions is still scarce. Research on mice with experimental autoimmune myocarditis has indicated that the AR regulates cardiac fibrosis by increasing the expression of miR$125 \mathrm{~b}$ [143]. Idiopathic pulmonary artery hypertension, chronic thromboembolic pulmonary hypertension, and acute pulmonary embolism are serious pulmonary vascular diseases. Recently, through the use of small RNA sequencing, Fabro et al. identified several miRNAs that were distinctly dysregulated in these diseases. Importantly, for two of them, let-7i-5p and miR-320a, the $A R$ was a target gene [70].

Chronic thromboembolic pulmonary hypertension (CTPH) is a potentially fatal disease that may occur as a rare complication following acute pulmonary embolism. The main cause of CTPH is a blockage in the blood vessels that may lead to heart failure [144]. Miao et al. identified miRNAs that are connected with CTPH [71]. MiR-3148, one of the key differentially expressed miRNAs, was downregulated in CTPH patients compared to in healthy donors. Importantly, the AR was found to be a target for miR-3148.

Shi et al. showed that hyperglycaemia triggered increased expression of miR-21-3p in cardiac fibroblasts. Interestingly, miR-21-3p repressed the expression of AR by binding to the $3^{\prime} \mathrm{UTR}$ of the $A R$ gene. As a consequence, AR downregulation led to the pyroptosis of the cardiac fibroblasts and collagen decomposition through caspase-1 activation [145].

\subsection{AR and miRNA in Ovarian Cancer and Polycystic Ovary Syndrome}

It has been shown that androgen signalling plays an important role in tumorigenesis and metastasis in ovarian cancer [146-148]. MiRNA profiling of serum from patients who were either at high or low risk of ovarian cancer development, revealed almost 140 differentially expressed miRNAs. Most of them were downregulated in patients with a high risk of ovarian cancer, and in the targeted genes involved in hypoxia and androgen signalling. The most downregulated and validated miRNAs were miR-93-5p, -19a-3p, -22$3 p,-362-5 p$, and $-210-3 p$. The authors suggested that the alteration of miRNA levels may contribute to the upregulation of genes involved in the androgen signalling pathway, such as macrophage colony-stimulating factor (CSF-1), macrophage colony-stimulating factor receptor (CSF-1R), and Erb-B2 receptor tyrosine kinase 4 (ErbB4), during the initial stages of ovarian cancer [72]. AR-miRNA interactions have also been reported in polycystic ovarian syndrome (PCO). Murri et al. identified 38 differentially expressed miRNAs in the serum of patients with PCO. Moreover, a prediction of putative miRNA target genes showed that several of these miRNAs, such as miR-30c-5p, miR-34c-5p, miR-142-3p, miR-199a-3p, miR-224-3p, miR-548d-3p, miR-597-5p, miR-598-3p, miR-1468-5p, miR-107, miR-151a3p, miR-199a-5p, and miR-153, may participate in AR signalling. Additionally, AR was predicted to be a target for miR-30c-5p, miR-199-5p, and miR-597 [73]. In another study, researchers investigated the miRNA levels in women with $\mathrm{PCO}$ (without insulin resistance) and estimated the free androgen index to determine androgen status. Importantly, studies 
have shown that the expression of miRNAs, such as miR-18b-5p, miR-424-5p, and let-7b-3p, although upregulated in PCO, does not correlate with androgen levels. Only for miR-1260a has a significant correlation with the free androgen index been demonstrated [74].

\subsection{AR and miRNA in Trophoblast and Placenta Development}

Shao et al. described a specific mechanism underlying the production of androgens and estrogens in the human placenta, which is regulated by miR-22 [75]. A higher miR22 level was observed in early-onset preeclampsia placentas compared to unexplained preterm labour placentas. In human placental trophoblasts, testosterone blocked estradiol production by upregulating the miR-22 level [75]. Recently, McWhorter et al. reported on the connection between let-7c miRNA and AR in the trophoblasts. In the human first-trimester trophoblast cell line, a trophoblast differentiation-related RNA-binding LIN28B protein was shown to regulate AR expression via let-7c. The inhibition of LIN28 resulted in reduced AR expression, increased levels of let-7, and increased trophoblast differentiation [76]. These observations are crucial for understanding the mechanisms underlying abnormalities in trophoblast cell differentiation, which can lead to placental disorders, including preeclampsia.

\subsection{AR and miRNA in Adipogenesis}

The AR is present in preadipocytes, and adipocytes and androgens are involved in adipose tissue functions and fat distribution in the body [149]. Recently, the interactions of AR with several miRNAs have been described in human adipogenesis [150]. For example, miR-130a was significantly upregulated under androgen stimulation during the early phase of adipogenesis, and $A R$ has been shown to be a target for miR-130a together with adiponectin (ADIPOQ) and tumour necrosis factor alpha (TNF $\alpha$ ) [77]. During adipogenesis, another miRNA, miR-375, is also regulated by androgen signalling; this miRNA is upregulated during adipogenic differentiation and downregulated following androgen treatment [78]. Interestingly, miR-375 was previously described as being upregulated in PCa tissues [151], as an inhibitor of nasopharyngeal carcinoma cells [152], as well as being related to diabetes [153]. The adipose tissue regulates insulin sensitivity, and the AR may play a role with androgens in pancreatic islet $\beta$ cells and diabetes [154]. Interestingly, a bioinformatic analysis of the key genes and molecular mechanisms involved in insulin resistance indicated that, among miRNAs that control differentially expressed genes in patients with subcutaneous insulin resistance, 96 miRNAs are involved in the downregulation of the AR, which was presented in the protein-protein interaction network [79]. This study presented a new potential relationship between miRNAs and the AR that is worth considering in further investigations into insulin resistance.

\section{Is There a Potential for miRNA-Based Therapy in AR-Dependent Malignancies?}

The above examples indicate a strong association between different miRNAs and AR. Although further studies involving large groups of patients are needed to validate the importance of these interactions, these works provide a hope for the development of new treatment strategies that target both AR and miRNAs. The ability of miRNAs to target multiple genes within a signalling pathway either in many types of cancer or in other diseases makes them very promising targets for the development of new therapeutic approaches. In general, miRNA-based therapeutics act as miRNA antagonists and mimics [155]. MiRNA mimics are chemically modified, double-stranded RNAs that can imitate endogenous mature miRNAs and restore their functionality [156]. MiRNA antagonists are single-stranded, antisense oligonucleotides that can be applied to intercept and degrade mature miRNAs [157]. The biggest challenge in this kind of therapy is deriving an efficient delivery system and acquiring an exact understanding of miRNA function in a specific disease. The delivery of synthetic miRNAs may be achieved through a few strategies, including oligonucleotides with chemical modifications, liposomes, polymers, hydrogels, nanoparticles, lentiviruses, and adenoviruses [18]. For example, Devulapally et al. pre- 
sented a model in which polymer nanoparticles could successfully deliver anti-miR-10b and anti-miR-21 in TNBC to block apoptosis and metastasis [158]. Exosomes have been shown to effectively deliver anti-miR-21 in PCa, allowing miR-21 downregulation and the blockade of cancer progression in the PC-3 human prostate cancer cell line [159]. Successful miR-155 and miR-124 delivery through the use of nanoparticles has also been described in ovarian cancer $[160,161]$. Montgomery and colleagues applied cholesterol conjugates to successfully deliver the miRNA-29 mimic to mouse lung tissue, which restored miRNA-29 function, decreased collagen expression, and repressed pulmonary fibrosis [162]. MiRNAs are not only targets for new therapies, but may also serve as prognostic biomarkers for various diseases. The indisputable advantage of using miRNAs as biomarkers is that miRNAs can be collected and detected in biofluids, such as serum, plasma, blood, tears, urine, or saliva, in a minimally invasive way [163-165]. Additionally, these small particles are stable, remaining so long after collection. The limitation of their usage is that the miRNA level required could be dependent on age, gender, and previously applied treatments $[166,167]$.

Regardless of the current limitations in the delivery of synthetic miRNAs to cells, one can expect that the combined use of miRNA with standard chemotherapy targeting AR may improve the outcome in future patients. Androgen deprivation therapy (ADT) is the first-line treatment used for patients with PCa [168]. Lowering androgen levels or blocking $\mathrm{AR}$ binding to testosterone prevents AR activation, and at least temporarily blocks PCa progression [169].

Combinations of different therapies with standard ADT are highly investigated. Javed et al. provide a summary of AR signalling in a normal and an aggressive form of PCa, and its relationships with miRNA and curcumin in potential therapeutic approaches. Curcumin is a compound of natural origin that has antioxidant, anti-inflammatory, and anti-cancer properties like preventing metastasis or limiting cancer cell proliferation $[170,171]$. MiRNAs, such as miR-34a, miR-143, miR-770-5p, miR-1247, and miR-145, showed elevated expression in the curcumin-treated PCa cell lines, and as a result, halted migration or cell proliferation was observed [172]. Fletcher et al. showed that the inhibitors of miR-346, miR-361-3p, and miR-197 were found to reduce the transcriptional activity of the AR, mRNA, and protein levels, and to significantly inhibit migration and invasion in the PCa cell culture. The inhibition of these miRNAs presents additive effects with antiandrogens that might be promising for combination approaches in PCa treatment [173]. In their study, Lin et al. used PCa and healthy prostate cell lines to examine the relationship between miR-31 and AR. It was discovered that miR-31 targets $A R$, and that its upregulation inhibits the expression of the AR at the protein and RNA levels, which suppresses PCa development. MiRNA-31 inhibits AR expression by binding to the coding region of the AR mRNA. Furthermore, the AR can suppress miR-31. These findings might help to design a therapy that supports existing therapies that focus on blocking AR activity [174]. It has been proven that miR-133a-5p targets fused in sarcoma (FUS) proteins and the AR in PCa cell lines. The overexpression of miR-133a-5p significantly downregulated FUS and AR, and suppressed the cell proliferation of the AR-positive PCa cell lines. Inversely, the inhibition of miR-133a$5 p$ enhanced the expression of FUS and AR, and consequently PCa cell proliferation [175]. Lyu et al. presented how DHT significantly upregulates let-7a expression and inhibits cell proliferation in the ER-, PR-, and AR+ BC cell lines. The inhibition of let-7a expression by antisense oligonucleotides revealed the upregulation of the MYC proto-oncogene (CMYC) and KRAS proto-oncogene (KRAS) protein, and elevated BC cell growth [176]. Recent results indicate that AR is able to suppress the formation of a new HCC vascularization pattern (vasculogenic mimicry) by regulating the circRNA7/miR-7-5p/VE-cadherin/Notch4 (circulating RNA 7/miR7-5p/vascular endothelial cadherin/notch receptor 4) signalling axis in HCC cell lines. The overexpression of AR upregulates miR-7-5p expression through the inhibition of circRNA7 in HCC cell lines. MiR-7-5p directly targets VE-cadherin and Notch4 and decreases their expression, which inhibits vasculogenic mimicry formation. To block this abnormal vascularization, the pattern inhibition of circRNA7 expression, as well as miR-7-5p expression recovery, could be effective [177]. 
The above-mentioned studies showing the relationships between AR and miRNAs in various diseases provide useful information for developing new therapies. Epigenetic therapies can aid and enhance the effect of existing approaches.

\section{Conclusions}

A growing amount of evidence is produced each year regarding the importance of the interactions that take place between miRNA and the AR. Although relationships between the miRNAs and the AR are predominantly studied in relation to prostate cancer and breast cancer, the role of miRNAs and the AR in other diseases has begun to emerge. The knowledge of the molecular mechanisms governing the mutual regulation of the AR and miRNAs will undoubtedly help us to design better therapeutic strategies and to provide more accurate molecular diagnostic, prognostic, and predictive biomarkers for specific diseases.

Author Contributions: Writing—original draft preparation, A.B.; writing—review and editing M.N., A.S.; supervision, A.K., M.N. and A.S. All authors have read and agreed to the published version of the manuscript.

Funding: This research was funded by the National Science Centre, Poland; grant number 2013/09/D/ NZ7/04185.

Institutional Review Board Statement: Not applicable.

Informed Consent Statement: Not applicable.

Conflicts of Interest: The authors declare no conflict of interest.

\section{References}

1. Kuiper, G.G.; Faber, P.W.; van Rooij, H.C.; van der Korput, J.A.; Ris-Stalpers, C.; Klaassen, P.; Trapman, J.; Brinkmann, A.O. Structural Organization of the Human Androgen Receptor Gene. J. Mol. Endocrinol. 1989, 2, R1-R4. [CrossRef] [PubMed]

2. Proverbs-Singh, T.; Feldman, J.L.; Morris, M.J.; Autio, K.A.; Traina, T.A. Targeting the Androgen Receptor in Prostate and Breast Cancer: Several New Agents in Development. Endocr. Relat. Cancer 2015, 22, R87-R106. [CrossRef] [PubMed]

3. Gucalp, A.; Traina, T.A. The Androgen Receptor: Is It a Promising Target? Ann. Surg. Oncol. 2017, 24, 2876-2880. [CrossRef] [PubMed]

4. Lubahn, D.B.; Joseph, D.R.; Sullivan, P.M.; Willard, H.F.; French, F.S.; Wilson, E.M. Cloning of Human Androgen Receptor Complementary DNA and Localization to the X Chromosome. Science 1988, 240, 327-330. [CrossRef]

5. O'Hara, L.; Smith, L.B. Androgen Receptor Roles in Spermatogenesis and Infertility. Best Pract. Res. Clin. Endocrinol. Metab. 2015, 29, 595-605. [CrossRef]

6. Anestis, A.; Zoi, I.; Papavassiliou, A.G.; Karamouzis, M.V. Androgen Receptor in Breast Cancer-Clinical and Preclinical Research Insights. Molecules 2020, 25, 358. [CrossRef]

7. Davey, R.A.; Grossmann, M. Androgen Receptor Structure, Function and Biology: From Bench to Bedside. Clin. Biochem. Rev. 2016, 37, 3-15.

8. Shukla, G.C.; Plaga, A.R.; Shankar, E.; Gupta, S. Androgen Receptor-Related Diseases: What Do We Know? Andrology 2016, 4, 366-381. [CrossRef]

9. Huang, W. MicroRNAs: Biomarkers, Diagnostics, and Therapeutics. In Bioinformatics in MicroRNA Research; Methods in Molecular Biology; Huang, J., Borchert, G.M., Dou, D., Huan, J., Lan, W., Tan, M., Wu, B., Eds.; Springer: New York, NY, USA, 2017; Volume 1617, pp. 57-67, ISBN 978-1-4939-7044-5.

10. Vishnoi, A.; Rani, S. MiRNA Biogenesis and Regulation of Diseases: An Overview. Methods Mol. Biol. Clifton N. J. 2017, 1509, 1-10. [CrossRef]

11. Bhowmick, S.S.; Saha, I.; Bhattacharjee, D.; Genovese, L.M.; Geraci, F. Genome-Wide Analysis of NGS Data to Compile CancerSpecific Panels of MiRNA Biomarkers. PLoS ONE 2018, 13, e0200353. [CrossRef]

12. Felekkis, K.; Touvana, E.; Stefanou, C.; Deltas, C. MicroRNAs: A Newly Described Class of Encoded Molecules That Play a Role in Health and Disease. Hippokratia 2010, 14, 236-240.

13. Ha, M.; Kim, V.N. Regulation of MicroRNA Biogenesis. Nat. Rev. Mol. Cell Biol. 2014, 15, 509-524. [CrossRef]

14. Vasudevan, S.; Tong, Y.; Steitz, J.A. Switching from Repression to Activation: MicroRNAs Can up-Regulate Translation. Science 2007, 318, 1931-1934. [CrossRef]

15. Doench, J.G.; Sharp, P.A. Specificity of MicroRNA Target Selection in Translational Repression. Genes Dev. 2004, 18, 504-511. [CrossRef]

16. Rc, F.; Kk, F.; Cb, B.; Dp, B. Most Mammalian MRNAs Are Conserved Targets of MicroRNAs. Genome Res. 2008, 19, 92-105. [CrossRef] 
17. Bautista-Sánchez, D.; Arriaga-Canon, C.; Pedroza-Torres, A.; De La Rosa-Velázquez, I.A.; González-Barrios, R.; Contreras-Espinosa, L.; Montiel-Manríquez, R.; Castro-Hernández, C.; Fragoso-Ontiveros, V.; Álvarez-Gómez, R.M.; et al. The Promising Role of MiR-21 as a Cancer Biomarker and Its Importance in RNA-Based Therapeutics. Mol. Ther. Nucleic Acids 2020, 20, 409-420. [CrossRef]

18. Tiwari, A.; Mukherjee, B.; Dixit, M. MicroRNA Key to Angiogenesis Regulation: MiRNA Biology and Therapy. Curr. Cancer Drug Targets 2018, 18, 266-277. [CrossRef]

19. Vienberg, S.; Geiger, J.; Madsen, S.; Dalgaard, L.T. MicroRNAs in Metabolism. Acta Physiol. 2017, 219, 346-361. [CrossRef]

20. Calin, G.A.; Dumitru, C.D.; Shimizu, M.; Bichi, R.; Zupo, S.; Noch, E.; Aldler, H.; Rattan, S.; Keating, M.; Rai, K.; et al. Frequent Deletions and Down-Regulation of Micro- RNA Genes MiR15 and MiR16 at 13q14 in Chronic Lymphocytic Leukemia. Proc. Natl. Acad. Sci. USA 2002, 99, 15524-15529. [CrossRef]

21. Wang, J.; Chen, J.; Sen, S. MicroRNA as Biomarkers and Diagnostics. J. Cell. Physiol. 2016, 231, 25-30. [CrossRef]

22. Wang, H.; Peng, R.; Wang, J.; Qin, Z.; Xue, L. Circulating MicroRNAs as Potential Cancer Biomarkers: The Advantage and Disadvantage. Clin. Epigenetics 2018, 10, 59. [CrossRef]

23. Macfarlane, L.-A.; Murphy, P.R. MicroRNA: Biogenesis, Function and Role in Cancer. Curr. Genom. 2010, 11, 537-561. [CrossRef]

24. Faruq, O.; Vecchione, A. MicroRNA: Diagnostic Perspective. Front. Med. 2015, 2. [CrossRef]

25. Lin, S.; Gregory, R.I. MicroRNA Biogenesis Pathways in Cancer. Nat. Rev. Cancer 2015, 15, 321-333. [CrossRef]

26. Banno, K.; Iida, M.; Yanokura, M.; Kisu, I.; Iwata, T.; Tominaga, E.; Tanaka, K.; Aoki, D. MicroRNA in Cervical Cancer: OncomiRs and Tumor Suppressor MiRs in Diagnosis and Treatment. Sci. World J. 2014, 2014, 178075. [CrossRef]

27. Achkar, N.P.; Cambiagno, D.A.; Manavella, P.A. MiRNA Biogenesis: A Dynamic Pathway. Trends Plant Sci. 2016, $21,1034-1044$. [CrossRef]

28. Lee, H.; Han, S.; Kwon, C.S.; Lee, D. Biogenesis and Regulation of the Let-7 MiRNAs and Their Functional Implications. Protein Cell 2016, 7, 100-113. [CrossRef]

29. Culig, Z.; Santer, F.R. Androgen Receptor Signaling in Prostate Cancer. Cancer Metastasis Rev. 2014, 33, 413-427. [CrossRef]

30. Waltering, K.K.; Porkka, K.P.; Jalava, S.E.; Urbanucci, A.; Kohonen, P.J.; Latonen, L.M.; Kallioniemi, O.P.; Jenster, G.; Visakorpi, T. Androgen Regulation of Micro-RNAs in Prostate Cancer. Prostate 2011, 71, 604-614. [CrossRef]

31. Fletcher, C.E.; Dart, D.A.; Sita-Lumsden, A.; Cheng, H.; Rennie, P.S.; Bevan, C.L. Androgen-Regulated Processing of the Oncomir MiR-27a, Which Targets Prohibitin in Prostate Cancer. Hum. Mol. Genet. 2012, 21, 3112-3127. [CrossRef]

32. Nilsson, E.M.; Laursen, K.B.; Whitchurch, J.; McWilliam, A.; Ødum, N.; Persson, J.L.; Heery, D.M.; Gudas, L.J.; Mongan, N.P MiR137 Is an Androgen Regulated Repressor of an Extended Network of Transcriptional Coregulators. Oncotarget 2015, 6, 35710-35725. [CrossRef] [PubMed]

33. Nadiminty, N.; Tummala, R.; Lou, W.; Zhu, Y.; Zhang, J.; Chen, X.; de Vere White, R.W.; Kung, H.-J.; Evans, C.P.; Gao, A.C. MicroRNA Let-7c Suppresses Androgen Receptor Expression and Activity via Regulation of Myc Expression in Prostate Cancer Cells*. J. Biol. Chem. 2012, 287, 1527-1537. [CrossRef] [PubMed]

34. Shi, X.-B.; Ma, A.-H.; Xue, L.; Li, M.; Nguyen, H.G.; Yang, J.C.; Tepper, C.G.; Gandour-Edwards, R.; Evans, C.P.; Kung, H.-J.; et al. MiR-124 and Androgen Receptor Signaling Inhibitors Repress Prostate Cancer Growth by Downregulating Androgen Receptor Splice Variants, EZH2, and Src. Cancer Res. 2015, 75, 5309-5317. [CrossRef] [PubMed]

35. Sikand, K.; Slaibi, J.E.; Singh, R.; Slane, S.D.; Shukla, G.C. MiR 488* Inhibits Androgen Receptor Expression in Prostate Carcinoma Cells. Int. J. Cancer 2011, 129, 810-819. [CrossRef]

36. Wang, R.; Wang, Z.; Cheng, Q.; Wang, G.; Bai, Z. Androgen Receptor Suppresses Prostate Cancer Cell Invasion via Altering the MiR-4496/ $\beta$-Catenin Signals. Biochem. Biophys. Res. Commun. 2018, 504, 82-88. [CrossRef]

37. Yang, S.; Zhang, J.; Zhang, Y.; Wan, X.; Zhang, C.; Huang, X.; Huang, W.; Pu, H.; Pei, C.; Wu, H.; et al. KDM1A Triggers Androgen-Induced MiRNA Transcription via H3K4me2 Demethylation and DNA Oxidation. The Prostate 2015, 75, 936-946. [CrossRef]

38. Pasqualini, L.; Bu, H.; Puhr, M.; Narisu, N.; Rainer, J.; Schlick, B.; Schäfer, G.; Angelova, M.; Trajanoski, Z.; Börno, S.T.; et al. MiR-22 and MiR-29a Are Members of the Androgen Receptor Cistrome Modulating LAMC1 and Mcl-1 in Prostate Cancer. Mol. Endocrinol. 2015, 29, 1037-1054. [CrossRef]

39. Mo, W.; Zhang, J.; Li, X.; Meng, D.; Gao, Y.; Yang, S.; Wan, X.; Zhou, C.; Guo, F.; Huang, Y.; et al. Identification of Novel AR-Targeted MicroRNAs Mediating Androgen Signalling through Critical Pathways to Regulate Cell Viability in Prostate Cancer. PLOS ONE 2013, 8, e56592. [CrossRef]

40. Kalinina, T.S.; Kononchuk, V.V.; Yakovleva, A.K.; Alekseenok, E.Y.; Sidorov, S.V.; Gulyaeva, L.F. Association between Lymph Node Status and Expression Levels of Androgen Receptor, MiR-185, MiR-205, and MiR-21 in Breast Cancer Subtypes. Int. J. Breast Cancer 2020, 2020, 3259393. [CrossRef]

41. Casaburi, I.; Cesario, G.M.; Donà, A.; Rizza, P.; Aquila, S.; Avena, P.; Lanzino, M.; Pellegrino, M.; Vivacqua, A.; Tucci, P.; et al. Androgens Downregulate MiR-21 Expression in Breast Cancer Cells Underlining the Protective Role of Androgen Receptor. Oncotarget 2016, 7, 12651-12661. [CrossRef]

42. Ahram, M.; Mustafa, E.; Zaza, R.; Abu Hammad, S.; Alhudhud, M.; Bawadi, R.; Zihlif, M. Differential Expression and Androgen Regulation of MicroRNAs and Metalloprotease 13 in Breast Cancer Cells. Cell Biol. Int. 2017, 41, 1345-1355. [CrossRef]

43. Al-Othman, N.; Hammad, H.; Ahram, M. Dihydrotestosterone Regulates Expression of CD44 via MiR-328-3p in Triple-Negative Breast Cancer Cells. Gene 2018, 675, 128-135. [CrossRef] 
44. Al-Momany, B.; Hammad, H.; Ahram, M. Dihydrotestosterone Induces Chemo-Resistance of Triple-Negative Breast MDA-MB-231 Cancer Cells towards Doxorubicin Independent of ABCG2 and MiR-328-3p. Curr. Mol. Pharmacol. 2021. [CrossRef]

45. Bandini, E.; Fanini, F.; Vannini, I.; Rossi, T.; Plousiou, M.; Tumedei, M.M.; Limarzi, F.; Maltoni, R.; Fabbri, F.; Hrelia, S.; et al. MiR-9-5p as a Regulator of the Androgen Receptor Pathway in Breast Cancer Cell Lines. Front. Cell Dev. Biol. 2020, 8, 579160. [CrossRef]

46. Shi, Y.; Yang, F.; Sun, Z.; Zhang, W.; Gu, J.; Guan, X. Differential MicroRNA Expression Is Associated with Androgen Receptor Expression in Breast Cancer. Mol. Med. Rep. 2017, 15, 29-36. [CrossRef]

47. Wang, S.; Yang, Y.; Cao, Y.-D.; Tang, X.-X.; Du, P. Androgen Downregulation of MiR-760 Promotes Prostate Cancer Cell Growth by Regulating IL6. Asian J. Androl. 2021, 23, 85-90. [CrossRef]

48. Zhang, L.; Zhang, W.; Li, H.; Tang, X.; Xu, S.; Wu, M.; Wan, L.; Su, F.; Zhang, Y. Five Circular RNAs in Metabolism Pathways Related to Prostate Cancer. Front. Genet. 2021, 12, 636419. [CrossRef]

49. Lin, Y.; Miao, Z.; Zhang, X.; Wei, X.; Hou, J.; Huang, Y.; Shen, B. Identification of Key MicroRNAs and Mechanisms in Prostate Cancer Evolution Based on Biomarker Prioritization Model and Carcinogenic Survey. Front. Genet. 2021, 11, 596826. [CrossRef]

50. Martínez-González, L.J.; Sánchez-Conde, V.; González-Cabezuelo, J.M.; Antunez-Rodríguez, A.; Andrés-León, E.; Robles-Fernandez, I.; Lorente, J.A.; Vázquez-Alonso, F.; Alvarez-Cubero, M.J. Identification of MicroRNAs as Viable Aggressiveness Biomarkers for Prostate Cancer. Biomedicines 2021, 9, 646. [CrossRef]

51. Rönnau, C.G.H.; Fussek, S.; Smit, F.P.; Aalders, T.W.; van Hooij, O.; Pinto, P.M.C.; Burchardt, M.; Schalken, J.A.; Verhaegh, G.W. Upregulation of MiR-3195, MiR-3687 and MiR-4417 Is Associated with Castration-Resistant Prostate Cancer. World J. Urol. 2021, 39, 3789-3797. [CrossRef]

52. Naidoo, M.; Levine, F.; Gillot, T.; Orunmuyi, A.T.; Olapade-Olaopa, E.O.; Ali, T.; Krampis, K.; Pan, C.; Dorsaint, P.; Sboner, A.; et al. MicroRNA-1205 Regulation of FRYL in Prostate Cancer. Front. Cell Dev. Biol. 2021, 9, 647485. [CrossRef]

53. Huang, Q.; Sun, Y.; Ma, X.; Gao, Y.; Li, X.; Niu, Y.; Zhang, X.; Chang, C. Androgen Receptor Increases Hematogenous Metastasis yet Decreases Lymphatic Metastasis of Renal Cell Carcinoma. Nat. Commun. 2017, 8, 918. [CrossRef]

54. Huang, Q.; Sun, Y.; Zhai, W.; Ma, X.; Shen, D.; Du, S.; You, B.; Niu, Y.; Huang, C.-P.; Zhang, X.; et al. Androgen Receptor Modulates Metastatic Routes of VHL Wild-Type Clear Cell Renal Cell Carcinoma in an Oxygen-Dependent Manner. Oncogene 2020, 39, 6677-6691. [CrossRef]

55. Wang, K.; Sun, Y.; Guo, C.; Liu, T.; Fei, X.; Chang, C. Androgen Receptor Regulates ASS1P3/MiR-34a-5p/ASS1 Signaling to Promote Renal Cell Carcinoma Cell Growth. Cell Death Dis. 2019, 10, 1-13. [CrossRef]

56. Chen, Y.; Sun, Y.; Rao, Q.; Xu, H.; Li, L.; Chang, C. Androgen Receptor (AR) Suppresses MiRNA-145 to Promote Renal Cell Carcinoma (RCC) Progression Independent of VHL Status. Oncotarget 2015, 6, 31203-31215. [CrossRef]

57. Wang, K.; Sun, Y.; Tao, W.; Fei, X.; Chang, C. Androgen Receptor (AR) Promotes Clear Cell Renal Cell Carcinoma (CcRCC) Migration and Invasion via Altering the CircHIAT1/MiR-195-5p/29a-3p/29c-3p/CDC42 Signals. Cancer Lett. 2017, $394,1-12$. [CrossRef]

58. Zhai, W.; Sun, Y.; Guo, C.; Hu, G.; Wang, M.; Zheng, J.; Lin, W.; Huang, Q.; Li, G.; Zheng, J.; et al. LncRNA-SARCC Suppresses Renal Cell Carcinoma (RCC) Progression via Altering the Androgen Receptor(AR)/MiRNA-143-3p Signals. Cell Death Differ. 2017, 24, 1502-1517. [CrossRef]

59. Yang, Z.; Chen, J.; Xie, H.; Liu, T.; Chen, Y.; Ma, Z.; Pei, X.; Yang, W.; Li, L. Androgen Receptor Suppresses Prostate Cancer Metastasis but Promotes Bladder Cancer Metastasis via Differentially Altering MiRNA525-5p/SLPI-Mediated Vasculogenic Mimicry Formation. Cancer Lett. 2020, 473, 118-129. [CrossRef]

60. Xiong, Y.; Wang, L.; Li, Y.; Chen, M.; He, W.; Qi, L. The Long Non-Coding RNA XIST Interacted with MiR-124 to Modulate Bladder Cancer Growth, Invasion and Migration by Targeting Androgen Receptor (AR). Cell. Physiol. Biochem. Int. J. Exp. Cell. Physiol. Biochem. Pharmacol. 2017, 43, 405-418. [CrossRef]

61. Chen, C.-C.; Hsieh, T.-F.; Huang, C.-P.; Yu, A.-L.; Chang, W.-L.; Shyr, C.-R. Androgen Receptor Expands the Population of Cancer Stem Cells in Upper Urinary Tract Urothelial Cell Carcinoma Cells. Am. J. Cancer Res. 2016, 6, 238-248. [CrossRef]

62. Chen, P.-J.; Yeh, S.-H.; Liu, W.-H.; Lin, C.-C.; Huang, H.-C.; Chen, C.-L.; Chen, D.-S.; Chen, P.-J. Androgen Pathway Stimulates MicroRNA-216a Transcription to Suppress the Tumor Suppressor in Lung Cancer-1 Gene in Early Hepatocarcinogenesis. Hepatol. Baltim. Md 2012, 56, 632-643. [CrossRef] [PubMed]

63. Ouyang, X.; Yao, L.; Liu, G.; Liu, S.; Gong, L.; Xiao, Y. Loss of Androgen Receptor Promotes HCC Invasion and Metastasis via Activating Circ-LNPEP/MiR-532-3p/RAB9A Signal under Hypoxia. Biochem. Biophys. Res. Commun. 2021, 557, 26-32. [CrossRef] [PubMed]

64. Huang, Z.-L.; Huang, X.-Y.; Huang, J.; Huang, X.-Y.; Xu, Y.-H.; Zhou, J.; Tang, Z.-Y. Multiple Omics Integration Reveals Key Circular RNAs in Hepatocellular Carcinoma. Front. Oncol. 2021, 11, 1141. [CrossRef] [PubMed]

65. Stanley, J.A.; Aruldhas, M.M.; Chandrasekaran, M.; Neelamohan, R.; Suthagar, E.; Annapoorna, K.; Sharmila, S.; Jayakumar, J.; Jayaraman, G.; Srinivasan, N.; et al. Androgen Receptor Expression in Human Thyroid Cancer Tissues: A Potential Mechanism Underlying the Gender Bias in the Incidence of Thyroid Cancers. J. Steroid Biochem. Mol. Biol. 2012, 130, 105-124. [CrossRef] [PubMed]

66. Lubov, J.; Maschietto, M.; Ibrahim, I.; Mlynarek, A.; Hier, M.; Kowalski, L.P.; Alaoui-Jamali, M.A.; Silva, S.D. da Meta-Analysis of MicroRNAs Expression in Head and Neck Cancer: Uncovering Association with Outcome and Mechanisms. Oncotarget 2017, 8, 55511-55524. [CrossRef] [PubMed] 
67. Park, M.; Kim, M.; Hwang, D.; Park, M.; Kim, W.K.; Kim, S.K.; Shin, J.; Park, E.S.; Kang, C.M.; Paik, Y.-K.; et al. Characterization of Gene Expression and Activated Signaling Pathways in Solid-Pseudopapillary Neoplasm of Pancreas. Mod. Pathol. 2014, 27, 580-593. [CrossRef]

68. Liang, L.; Wei, D.-M.; Li, J.-J.; Luo, D.-Z.; Chen, G.; Dang, Y.-W.; Cai, X.-Y. Prognostic MicroRNAs and Their Potential Molecular Mechanism in Pancreatic Cancer: A Study Based on The Cancer Genome Atlas and Bioinformatics Investigation. Mol. Med. Rep. 2018, 17, 939-951. [CrossRef]

69. Jin, X.; Guan, Y.; Sheng, H.; Liu, Y. Crosstalk in Competing Endogenous RNA Network Reveals the Complex Molecular Mechanism Underlying Lung Cancer. Oncotarget 2017, 8, 91270-91280. [CrossRef]

70. Fabro, A.T.; Machado-Rugolo, J.; Baldavira, C.M.; Prieto, T.G.; Farhat, C.; Rotea ManGone, F.R.; Batah, S.S.; Cruvinel, H.R.; Aldá, M.A.; Monteiro, J.S.; et al. Circulating Plasma MiRNA and Clinical/Hemodynamic Characteristics Provide Additional Predictive Information About Acute Pulmonary Thromboembolism, Chronic Thromboembolic Pulmonary Hypertension and Idiopathic Pulmonary Hypertension. Front. Pharmacol. 2021, 12, 648769. [CrossRef]

71. Miao, R.; Wang, Y.; Wan, J.; Leng, D.; Gong, J.; Li, J.; Zhang, Y.; Pang, W.; Zhai, Z.; Yang, Y. Microarray Analysis and Detection of MicroRNAs Associated with Chronic Thromboembolic Pulmonary Hypertension. BioMed Res. Int. 2017, 2017, 8529796. [CrossRef]

72. Pandey, R.; Woo, H.-H.; Varghese, F.; Zhou, M.; Chambers, S.K. Circulating MiRNA Profiling of Women at High Risk for Ovarian Cancer. Transl. Oncol. 2019, 12, 714-725. [CrossRef]

73. Murri, M.; Insenser, M.; Fernández-Durán, E.; San-Millán, J.L.; Luque-Ramírez, M.; Escobar-Morreale, H.F. Non-Targeted Profiling of Circulating MicroRNAs in Women with Polycystic Ovary Syndrome (PCOS): Effects of Obesity and Sex Hormones. Metabolism 2018, 86, 49-60. [CrossRef]

74. Butler, A.E.; Ramachandran, V.; Cunningham, T.K.; David, R.; Gooderham, N.J.; Benurwar, M.; Dargham, S.R.; Hayat, S.; Sathyapalan, T.; Najafi-Shoushtari, S.H.; et al. Increased MicroRNA Levels in Women With Polycystic Ovarian Syndrome but Without Insulin Resistance: A Pilot Prospective Study. Front. Endocrinol. 2020, 11, 571357. [CrossRef]

75. Shao, X.; Liu, Y.; Liu, M.; Wang, Y.; Yan, L.; Wang, H.; Ma, L.; Li, Y.-X.; Zhao, Y.; Wang, Y.-L. Testosterone Represses Estrogen Signaling by Upregulating MiR-22: A Mechanism for Imbalanced Steroid Hormone Production in Preeclampsia. Hypertens. Dallas Tex 1979 2017, 69, 721-730. [CrossRef]

76. McWhorter, E.S.; West, R.C.; Russ, J.E.; Ali, A.; Winger, Q.A.; Bouma, G.J. LIN28B Regulates Androgen Receptor in Human Trophoblast Cells through Let-7c. Mol. Reprod. Dev. 2019, 86, 1086-1093. [CrossRef]

77. Greither, T.; Wenzel, C.; Jansen, J.; Kraus, M.; Wabitsch, M.; Behre, H.M. MiR-130a in the Adipogenesis of Human SGBS Preadipocytes and Its Susceptibility to Androgen Regulation. Adipocyte 2020, 9, 197-205. [CrossRef]

78. Kraus, M.; Greither, T.; Wenzel, C.; Bräuer-Hartmann, D.; Wabitsch, M.; Behre, H.M. Inhibition of Adipogenic Differentiation of Human SGBS Preadipocytes by Androgen-Regulated MicroRNA MiR-375. Mol. Cell. Endocrinol. 2015, 414, 177-185. [CrossRef]

79. Pujar, M.K.; Vastrad, B.; Vastrad, C. Integrative Analyses of Genes Associated with Subcutaneous Insulin Resistance. Biomolecules 2019, 9, 37. [CrossRef]

80. Xie, H.; Xiao, R.; He, Y.; He, L.; Xie, C.; Chen, J.; Hong, Y. MicroRNA-100 Inhibits Breast Cancer Cell Proliferation, Invasion and Migration by Targeting FOXA1. Oncol. Lett. 2021, 22, 1-10. [CrossRef]

81. Yang, Y.; Jia, B.; Zhao, X.; Wang, Y.; Ye, W. MiR-93-5p May Be an Important Oncogene in Prostate Cancer by Bioinformatics Analysis. J. Cell. Biochem. 2019, 120, 10463-10483. [CrossRef]

82. Ye, D.; Shen, Z.; Zhou, S. Function of MicroRNA-145 and Mechanisms Underlying Its Role in Malignant Tumor Diagnosis and Treatment. Cancer Manag. Res. 2019, 11, 969-979. [CrossRef] [PubMed]

83. Wang, X.; Wu, Q.; Xu, B.; Wang, P.; Fan, W.; Cai, Y.; Gu, X.; Meng, F. MiR-124 Exerts Tumor Suppressive Functions on the Cell Proliferation, Motility and Angiogenesis of Bladder Cancer by Fine-Tuning UHRF1. FEBS J. 2015, 282, 4376-4388. [CrossRef]

84. Wang, Y.; Yang, Z.; Wang, L.; Sun, L.; Liu, Z.; Li, Q.; Yao, B.; Chen, T.; Wang, C.; Yang, W.; et al. MiR-532-3p Promotes Hepatocellular Carcinoma Progression by Targeting PTPRT. Biomed. Pharmacother. Biomedecine Pharmacother. 2019, 109, 991-999. [CrossRef]

85. Sun, Y.; Zhang, L.; Zhang, S. MicroRNA-124-3p Inhibits Tumourigenesis by Targeting Mitogen-Activated Protein Kinase 4 in Papillary Thyroid Carcinoma. Cell Biochem. Funct. 2020, 38, 1017-1024. [CrossRef]

86. Chen, Z.; Jin, Y.; Yu, D.; Wang, A.; Mahjabeen, I.; Wang, C.; Liu, X.; Zhou, X. Down-Regulation of the MicroRNA-99 Family Members in Head and Neck Squamous Cell Carcinoma. Oral Oncol. 2012, 48, 686-691. [CrossRef]

87. Diaz-Riascos, Z.V.; Ginesta, M.M.; Fabregat, J.; Serrano, T.; Busquets, J.; Buscail, L.; Cordelier, P.; Capellá, G. Expression and Role of MicroRNAs from the MiR-200 Family in the Tumor Formation and Metastatic Propensity of Pancreatic Cancer. Mol. Ther. Nucleic Acids 2019, 17, 491-503. [CrossRef]

88. Sun, B.; Hua, J.; Cui, H.; Liu, H.; Zhang, K.; Zhou, H. MicroRNA-1197 Downregulation Inhibits Proliferation and Migration in Human Non- Small Cell Lung Cancer Cells by Upregulating HOXC11. Biomed. Pharmacother. 2019, 117, 109041. [CrossRef] [PubMed]

89. Chen, X.; Chen, S.; Xiu, Y.-L.; Sun, K.-X.; Zong, Z.-H.; Zhao, Y. RhoC Is a Major Target of MicroRNA-93-5P in Epithelial Ovarian Carcinoma Tumorigenesis and Progression. Mol. Cancer 2015, 14, 31. [CrossRef]

90. Burger, H.G. Androgen Production in Women. Fertil. Steril. 2002, 77, 3-5. [CrossRef]

91. Bienenfeld, A.; Azarchi, S.; Lo Sicco, K.; Marchbein, S.; Shapiro, J.; Nagler, A.R. Androgens in Women: Androgen-Mediated Skin Disease and Patient Evaluation. J. Am. Acad. Dermatol. 2019, 80, 1497-1506. [CrossRef] 
92. Niemeier, L.A.; Dabbs, D.J.; Beriwal, S.; Striebel, J.M.; Bhargava, R. Androgen Receptor in Breast Cancer: Expression in Estrogen Receptor-Positive Tumors and in Estrogen Receptor-Negative Tumors with Apocrine Differentiation. Mod. Pathol. 2010, 23, 205-212. [CrossRef] [PubMed]

93. Park, S.; Koo, J.; Park, H.S.; Kim, J.-H.; Choi, S.-Y.; Lee, J.H.; Park, B.-W.; Lee, K.S. Expression of Androgen Receptors in Primary Breast Cancer. Ann. Oncol. Off. J. Eur. Soc. Med. Oncol. 2010, 21, 488-492. [CrossRef] [PubMed]

94. Bockhorn, J.; Yee, K.; Chang, Y.-F.; Prat, A.; Huo, D.; Nwachukwu, C.; Dalton, R.; Huang, S.; Swanson, K.E.; Perou, C.M.; et al. MicroRNA-30c Targets Cytoskeleton Genes Involved in Breast Cancer Cell Invasion. Breast Cancer Res. Treat. 2013, 137, 373-382. [CrossRef] [PubMed]

95. Giovannelli, P.; Di Donato, M.; Galasso, G.; Di Zazzo, E.; Bilancio, A.; Migliaccio, A. The Androgen Receptor in Breast Cancer. Front. Endocrinol. 2018, 9, 492. [CrossRef]

96. Al-Othman, N.; Ahram, M.; Alqaraleh, M. Role of Androgen and MicroRNA in Triple-Negative Breast Cancer. Breast Dis. 2020, 39, 15-27. [CrossRef]

97. Hagman, Z.; Haflidadóttir, B.S.; Ceder, J.A.; Larne, O.; Bjartell, A.; Lilja, H.; Edsjö, A.; Ceder, Y. MiR-205 Negatively Regulates the Androgen Receptor and Is Associated with Adverse Outcome of Prostate Cancer Patients. Br. J. Cancer 2013, 108, $1668-1676$. [CrossRef]

98. Liu, C.; Chen, Z.; Hu, X.; Wang, L.; Li, C.; Xue, J.; Zhang, P.; Chen, W.; Jiang, A. MicroRNA-185 Downregulates Androgen Receptor Expression in the LNCaP Prostate Carcinoma Cell Line. Mol. Med. Rep. 2015, 11, 4625-4632. [CrossRef]

99. Ribas, J.; Ni, X.; Haffner, M.; Wentzel, E.A.; Salmasi, A.H.; Chowdhury, W.H.; Kudrolli, T.A.; Yegnasubramanian, S.; Luo, J.; Rodriguez, R.; et al. MiR-21: An Androgen Receptor-Regulated MicroRNA That Promotes Hormone-Dependent and HormoneIndependent Prostate Cancer Growth. Cancer Res. 2009, 69, 7165-7169. [CrossRef]

100. Yan, L.X.; Wu, Q.N.; Zhang, Y.; Li, Y.Y.; Liao, D.Z.; Hou, J.H.; Fu, J.; Zeng, M.S.; Yun, J.P.; Wu, Q.L.; et al. Knockdown of MiR-21 in Human Breast Cancer Cell Lines Inhibits Proliferation, in Vitro Migration and in Vivo Tumor Growth. Breast Cancer Res. BCR 2011, 13, R2. [CrossRef]

101. Guan, C.; Zhang, L.; Wang, S.; Long, L.; Zhou, H.; Qian, S.; Ma, M.; Bai, F.; Meng, Q.H.; Lyu, J. Upregulation of MicroRNA-21 Promotes Tumorigenesis of Prostate Cancer Cells by Targeting KLF5. Cancer Biol. Ther. 2019, 20, 1149-1161. [CrossRef]

102. Esquela-Kerscher, A.; Slack, F.J. Oncomirs - MicroRNAs with a Role in Cancer. Nat. Rev. Cancer 2006, 6, 259-269. [CrossRef]

103. Nohata, N.; Hanazawa, T.; Enokida, H.; Seki, N. MicroRNA-1/133a and MicroRNA-206/133b Clusters: Dysregulation and Functional Roles in Human Cancers. Oncotarget 2012, 3, 9-21. [CrossRef]

104. Li, X.; Zeng, Z.; Wang, J.; Wu, Y.; Chen, W.; Zheng, L.; Xi, T.; Wang, A.; Lu, Y. MicroRNA-9 and Breast Cancer. Biomed. Pharmacother. 2020, 122, 109687. [CrossRef]

105. Castellano, L.; Giamas, G.; Jacob, J.; Coombes, R.C.; Lucchesi, W.; Thiruchelvam, P.; Barton, G.; Jiao, L.R.; Wait, R.; Waxman, J.; et al. The Estrogen Receptor- $\alpha$-Induced MicroRNA Signature Regulates Itself and Its Transcriptional Response. Proc. Natl. Acad. Sci. USA 2009. [CrossRef]

106. Leung, C.-M.; Chen, T.-W.; Li, S.-C.; Ho, M.-R.; Hu, L.-Y.; Liu, W.-S.; Wu, T.T.; Hsu, P.-C.; Chang, H.-T.; Tsai, K.-W. MicroRNA Expression Profiles in Human Breast Cancer Cells after Multifraction and Single-Dose Radiation Treatment. Oncol. Rep. 2014, 31, 2147-2156. [CrossRef]

107. Ottman, R.; Levy, J.; Grizzle, W.E.; Chakrabarti, R. The Other Face of MiR-17-92a Cluster, Exhibiting Tumor Suppressor Effects in Prostate Cancer. Oncotarget 2016, 7, 73739-73753. [CrossRef]

108. Walter, B.A.; Valera, V.A.; Pinto, P.A.; Merino, M.J. Comprehensive MicroRNA Profiling of Prostate Cancer. J. Cancer 2013, 4, 350-357. [CrossRef]

109. Epis, M.R.; Giles, K.M.; Barker, A.; Kendrick, T.S.; Leedman, P.J. MiR-331-3p Regulates ERBB-2 Expression and Androgen Receptor Signaling in Prostate Cancer*. J. Biol. Chem. 2009, 284, 24696-24704. [CrossRef]

110. Stope, M.B.; Bradl, J.; Peters, S.; Streitbörger, A.; Weiss, M.; Zimmermann, U.; Walther, R.; Lillig, C.H.; Burchardt, M. Shortened Isoforms of the Androgen Receptor Are Regulated by the Cytoprotective Heat-Shock Protein HSPB1 and the Tumor-Suppressive MicroRNA MiR-1 in Prostate Cancer Cells. Anticancer Res. 2013, 33, 4921-4926.

111. Stope, M.B.; Stender, C.; Schubert, T.; Peters, S.; Weiss, M.; Ziegler, P.; Zimmermann, U.; Walther, R.; Burchardt, M. Heat-Shock Protein HSPB1 Attenuates MicroRNA MiR-1 Expression Thereby Restoring Oncogenic Pathways in Prostate Cancer Cells. Anticancer Res. 2014, 34, 3475-3480.

112. Stope, M.B.; Peters, S.; Großebrummel, H.; Zimmermann, U.; Walther, R.; Burchardt, M. Androgen Receptor (AR) Inhibitor ErbB3-Binding Protein-1 (Ebp1) Is Not Targeted by the Newly Identified AR Controlling Signaling Axis Heat-Shock Protein HSP27 and MicroRNA MiR-1 in Prostate Cancer Cells. World J. Urol. 2015, 33, 323-327. [CrossRef]

113. Matin, F.; Jeet, V.; Srinivasan, S.; Cristino, A.S.; Panchadsaram, J.; Clements, J.A.; Batra, J. On behalf of Australian Prostate Cancer BioResource MicroRNA-3162-5p-Mediated Crosstalk between Kallikrein Family Members Including Prostate-Specific Antigen in Prostate Cancer. Clin. Chem. 2019, 65, 771-780. [CrossRef]

114. Larne, O.; Hagman, Z.; Lilja, H.; Bjartell, A.; Edsjö, A.; Ceder, Y. MiR-145 Suppress the Androgen Receptor in Prostate Cancer Cells and Correlates to Prostate Cancer Prognosis. Carcinogenesis 2015, 36, 858-866. [CrossRef]

115. Xie, Z.-C.; Huang, J.-C.; Zhang, L.-J.; Gan, B.-L.; Wen, D.-Y.; Chen, G.; Li, S.-H.; Yan, H.-B. Exploration of the Diagnostic Value and Molecular Mechanism of MiR-1 in Prostate Cancer: A Study Based on Meta-Analyses and Bioinformatics. Mol. Med. Rep. 2018, 18, 5630-5646. [CrossRef] 
116. Hudson, R.S.; Yi, M.; Esposito, D.; Watkins, S.K.; Hurwitz, A.A.; Yfantis, H.G.; Lee, D.H.; Borin, J.F.; Naslund, M.J.; Alexander, R.B.; et al. MicroRNA-1 Is a Candidate Tumor Suppressor and Prognostic Marker in Human Prostate Cancer. Nucleic Acids Res. 2012, 40, 3689-3703. [CrossRef]

117. Xu, Y.; Qin, S.; An, T.; Tang, Y.; Huang, Y.; Zheng, L. MiR-145 Detection in Urinary Extracellular Vesicles Increase Diagnostic Efficiency of Prostate Cancer Based on Hydrostatic Filtration Dialysis Method. Prostate 2017, 77, 1167-1175. [CrossRef]

118. Chandrasekar, T.; Yang, J.C.; Gao, A.C.; Evans, C.P. Mechanisms of Resistance in Castration-Resistant Prostate Cancer (CRPC). Transl. Androl. Urol. 2015, 4, 365-380. [CrossRef]

119. Ashwal-Fluss, R.; Meyer, M.; Pamudurti, N.R.; Ivanov, A.; Bartok, O.; Hanan, M.; Evantal, N.; Memczak, S.; Rajewsky, N.; Kadener, S. CircRNA Biogenesis Competes with Pre-MRNA Splicing. Mol. Cell 2014, 56, 55-66. [CrossRef]

120. Salzman, J.; Gawad, C.; Wang, P.L.; Lacayo, N.; Brown, P.O. Circular RNAs Are the Predominant Transcript Isoform from Hundreds of Human Genes in Diverse Cell Types. PLoS ONE 2012, 7, e30733. [CrossRef] [PubMed]

121. Tay, Y.; Rinn, J.; Pandolfi, P.P. The Multilayered Complexity of CeRNA Crosstalk and Competition. Nature 2014, 505, 344-352. [CrossRef] [PubMed]

122. Hansen, T.B.; Jensen, T.I.; Clausen, B.H.; Bramsen, J.B.; Finsen, B.; Damgaard, C.K.; Kjems, J. Natural RNA Circles Function as Efficient MicroRNA Sponges. Nature 2013, 495, 384-388. [CrossRef] [PubMed]

123. Sun, Y.; Hu, B.; Wang, Y.; Li, Z.; Wu, J.; Yang, Y.; Wei, Y.; Peng, X.; Chen, H.; Chen, R.; et al. MiR-216a-5p Inhibits Malignant Progression in Small Cell Lung Cancer: Involvement of the Bcl-2 Family Proteins. Cancer Manag. Res. 2018, 10, 4735-4745. [CrossRef] [PubMed]

124. Mekhail, S.M.; Yousef, P.G.; Jackinsky, S.W.; Pasic, M.; Yousef, G.M. MiRNA in Prostate Cancer: New Prospects for Old Challenges. EJIFCC 2014, 25, 79-98. [PubMed]

125. Catto, J.W.F.; Alcaraz, A.; Bjartell, A.S.; De Vere White, R.; Evans, C.P.; Fussel, S.; Hamdy, F.C.; Kallioniemi, O.; Mengual, L.; Schlomm, T.; et al. MicroRNA in Prostate, Bladder, and Kidney Cancer: A Systematic Review. Eur. Urol. 2011, 59, 671-681. [CrossRef] [PubMed]

126. Fendler, A.; Stephan, C.; Yousef, G.M.; Jung, K. MicroRNAs as Regulators of Signal Transduction in Urological Tumors. Clin. Chem. 2011, 57, 954-968. [CrossRef]

127. Chow, W.-H.; Dong, L.M.; Devesa, S.S. Epidemiology and Risk Factors for Kidney Cancer. Nat. Rev. Urol. $2010,7,245-257$. [CrossRef]

128. Jian, Y.; Yang, K.; Sun, X.; Zhao, J.; Huang, K.; Aldanakh, A.; Xu, Z.; Wu, H.; Xu, Q.; Zhang, L.; et al. Current Advance of Immune Evasion Mechanisms and Emerging Immunotherapies in Renal Cell Carcinoma. Front. Immunol. 2021, 12, 639636. [CrossRef]

129. Yu, G.; Li, H.; Wang, J.; Gumireddy, K.; Li, A.; Yao, W.; Tang, K.; Xiao, W.; Hu, J.; Xiao, H.; et al. MiRNA-34a Suppresses Cell Proliferation and Metastasis by Targeting CD44 in Human Renal Carcinoma Cells. J. Urol. 2014, 192, 1229-1237. [CrossRef]

130. Yamamura, S.; Saini, S.; Majid, S.; Hirata, H.; Ueno, K.; Chang, I.; Tanaka, Y.; Gupta, A.; Dahiya, R. MicroRNA-34a Suppresses Malignant Transformation by Targeting c-Myc Transcriptional Complexes in Human Renal Cell Carcinoma. Carcinogenesis 2012, 33, 294-300. [CrossRef]

131. Evan, A.P.; Worcester, E.M.; Coe, F.L.; Williams, J.; Lingeman, J.E. Mechanisms of Human Kidney Stone Formation. Urolithiasis 2015, 43, 19-32. [CrossRef]

132. Zhu, W.; Zhao, Z.; Chou, F.; Zuo, L.; Liu, T.; Yeh, S.; Bushinsky, D.; Zeng, G.; Chang, C. Loss of the Androgen Receptor Suppresses Intrarenal Calcium Oxalate Crystals Deposition via Altering Macrophage Recruitment/M2 Polarization with Change of the MiR-185-5p/CSF-1 Signals. Cell Death Dis. 2019, 10, 275. [CrossRef]

133. Zhang, H.; Li, X.-X.; Yang, Y.; Zhang, Y.; Wang, H.-Y.; Zheng, X.F.S. Significance and Mechanism of Androgen Receptor Overexpression and Androgen Receptor/Mechanistic Target of Rapamycin Cross-Talk in Hepatocellular Carcinoma. Hepatology 2018, 67, 2271-2286. [CrossRef]

134. Tian, Y.; Xie, X.; Lin, Y.; Tan, G.; Zhong, W. Androgen Receptor in Hepatocarcinogenesis: Recent Developments and Perspectives (Review). Oncol. Lett. 2015, 9, 1983-1988. [CrossRef]

135. Sun, J.; Lu, H.; Wang, X.; Jin, H. MicroRNAs in Hepatocellular Carcinoma: Regulation, Function, and Clinical Implications. Sci. World J. 2013, 2013, e924206. [CrossRef]

136. Du, X.; Zhang, J.; Wang, J.; Lin, X.; Ding, F. Role of MiRNA in Lung Cancer-Potential Biomarkers and Therapies. Curr. Pharm. Des. 2018, 23, 5997-6010. [CrossRef]

137. Bouhaddioui, W.; Provost, P.R.; Tremblay, Y. Expression Profile of Androgen-Modulated MicroRNAs in the Fetal Murine Lung. Biol. Sex Differ. 2016, 7, 20. [CrossRef]

138. Beattie, C.W.; Hansen, N.W.; Thomas, P.A. Steroid Receptors in Human Lung Cancer. Cancer Res. 1985, 45, 4206-4214.

139. Kaiser, U.; Hofmann, J.; Schilli, M.; Wegmann, B.; Klotz, U.; Wedel, S.; Virmani, A.K.; Wollmer, E.; Branscheid, D.; Gazdar, A.F.; et al. Steroid-Hormone Receptors in Cell Lines and Tumor Biopsies of Human Lung Cancer. Int. J. Cancer 1996, 67, 357-364. [CrossRef]

140. Wu, M.; Wang, G.; Tian, W.; Deng, Y.; Xu, Y. MiRNA-Based Therapeutics for Lung Cancer. Curr. Pharm. Des. 2018, 23, 5989-5996. [CrossRef]

141. Kalayinia, S.; Arjmand, F.; Maleki, M.; Malakootian, M.; Singh, C.P. MicroRNAs: Roles in Cardiovascular Development and Disease. Cardiovasc. Pathol. 2021, 50, 107296. [CrossRef] 
142. Huang, C.-K.; Lee, S.O.; Chang, E.; Pang, H.; Chang, C. Androgen Receptor (AR) in Cardiovascular Diseases. J. Endocrinol. 2016, 229, R1-R16. [CrossRef] [PubMed]

143. Wang, Y.; Ma, W.; Lu, S.; Yan, L.; Hu, F.; Wang, Z.; Cheng, B. Androgen Receptor Regulates Cardiac Fibrosis in Mice with Experimental Autoimmune Myocarditis by Increasing MicroRNA-125b Expression. Biochem. Biophys. Res. Commun. 2018, 506, 130-136. [CrossRef] [PubMed]

144. O'Connell, C.; Montani, D.; Savale, L.; Sitbon, O.; Parent, F.; Seferian, A.; Bulifon, S.; Fadel, E.; Mercier, O.; Mussot, S.; et al. Chronic Thromboembolic Pulmonary Hypertension. Presse Médicale 2015, 44, e409-e416. [CrossRef] [PubMed]

145. Shi, P.; Zhao, X.-D.; Shi, K.-H.; Ding, X.-S.; Tao, H. MiR-21-3p Triggers Cardiac Fibroblasts Pyroptosis in Diabetic Cardiac Fibrosis via Inhibiting Androgen Receptor. Exp. Cell Res. 2021, 399, 112464. [CrossRef] [PubMed]

146. Chung, W.-M.; Chen, L.; Chang, W.-C.; Su, S.-Y.; Hung, Y.-C.; Ma, W.-L. Androgen/Androgen Receptor Signaling in Ovarian Cancer: Molecular Regulation and Therapeutic Potentials. Int. J. Mol. Sci. 2021, 22, 7748. [CrossRef]

147. Gibson, D.A.; Simitsidellis, I.; Collins, F.; Saunders, P.T.K. Evidence of Androgen Action in Endometrial and Ovarian Cancers. Endocr. Relat. Cancer 2014, 21, T203-T218. [CrossRef]

148. Zheng, H.; Kavanagh, J.J.; Hu, W.; Liao, Q.; Fu, S. Hormonal Therapy in Ovarian Cancer. Int. J. Gynecol. Cancer Off. J. Int. Gynecol. Cancer Soc. 2007, 17, 325-338. [CrossRef]

149. Tchernof, A.; Brochu, D.; Maltais-Payette, I.; Mansour, M.F.; Marchand, G.B.; Carreau, A.-M.; Kapeluto, J. Androgens and the Regulation of Adiposity and Body Fat Distribution in Humans. Compr. Physiol. 2018, 8, 1253-1290. [CrossRef]

150. Jansen, J.; Greither, T.; Behre, H.M. Androgen-Regulated MicroRNAs (AndroMiRs) as Novel Players in Adipogenesis. Int. J. Mol. Sci. 2019, 20, 5767. [CrossRef]

151. He, S.; Shi, J.; Mao, J.; Luo, X.; Liu, W.; Liu, R.; Yang, F. The Expression of MiR-375 in Prostate Cancer: A Study Based on GEO, TCGA Data and Bioinformatics Analysis. Pathol. Res. Pract. 2019, 215, 152375. [CrossRef]

152. Jia-yuan, X.; Wei, S.; Fang-fang, L.; Zhi-jian, D.; Long-he, C.; Sen, L. MiR-375 Inhibits the Proliferation and Invasion of Nasopharyngeal Carcinoma Cells by Suppressing PDK1. BioMed Res. Int. 2020, 2020, 9704245. [CrossRef]

153. Li, X. MiR-375, a MicroRNA Related to Diabetes. Gene 2014, 533, 1-4. [CrossRef]

154. Smith, U.; Kahn, B.B. Adipose Tissue Regulates Insulin Sensitivity: Role of Adipogenesis, de Novo Lipogenesis and Novel Lipids. J. Intern. Med. 2016, 280, 465-475. [CrossRef]

155. Baumann, V.; Winkler, J. MiRNA-Based Therapies: Strategies and Delivery Platforms for Oligonucleotide and NonOligonucleotide Agents. Future Med. Chem. 2014, 6, 1967-1984. [CrossRef]

156. Lu, T.X.; Rothenberg, M.E. MicroRNA. J. Allergy Clin. Immunol. 2018, 141, 1202-1207. [CrossRef]

157. Stenvang, J.; Kauppinen, S. MicroRNAs as Targets for Antisense-Based Therapeutics. Expert Opin. Biol. Ther. 2008, 8, 59-81. [CrossRef]

158. Devulapally, R.; Sekar, N.M.; Sekar, T.V.; Foygel, K.; Massoud, T.F.; Willmann, J.K.; Paulmurugan, R. Polymer Nanoparticles Mediated Codelivery of AntimiR-10b and AntimiR-21 for Achieving Triple Negative Breast Cancer Therapy. ACS Nano 2015, 9 , 2290-2302. [CrossRef]

159. Alhasan, A.H.; Patel, P.C.; Choi, C.H.J.; Mirkin, C.A. Exosome Encased Spherical Nucleic Acid Gold Nanoparticle Conjugates As Potent MicroRNA Regulation Agents. Small Weinh. Bergstr. Ger. 2014, 10, 186-192. [CrossRef]

160. Cubillos-Ruiz, J.R.; Baird, J.R.; Tesone, A.J.; Rutkowski, M.R.; Scarlett, U.K.; Camposeco-Jacobs, A.L.; Anadon-Arnillas, J.; Harwood, N.M.; Korc, M.; Fiering, S.N.; et al. Reprogramming Tumor-Associated Dendritic Cells In Vivo Using Microrna Mimetics Triggers Protective Immunity Against Ovarian Cancer. Cancer Res. 2012, 72, 1683-1693. [CrossRef]

161. Seviour, E.G.; Sehgal, V.; Lu, Y.; Luo, Z.; Moss, T.; Zhang, F.; Hill, S.M.; Liu, W.; Maiti, S.N.; Cooper, L.; et al. Functional Proteomics Identifies MiRNAs to Target a P27/Myc/Phospho-Rb Signature in Breast and Ovarian Cancer. Oncogene 2016, 35, 691-701. [CrossRef]

162. Montgomery, R.L.; Yu, G.; Latimer, P.A.; Stack, C.; Robinson, K.; Dalby, C.M.; Kaminski, N.; van Rooij, E. MicroRNA Mimicry Blocks Pulmonary Fibrosis. EMBO Mol. Med. 2014, 6, 1347-1356. [CrossRef]

163. Backes, C.; Meese, E.; Keller, A. Specific MiRNA Disease Biomarkers in Blood, Serum and Plasma: Challenges and Prospects. Mol. Diagn. Ther. 2016, 20, 509-518. [CrossRef] [PubMed]

164. Ghafouri-Fard, S.; Shoorei, H.; Taheri, M. MiRNA Profile in Ovarian Cancer. Exp. Mol. Pathol. 2020, 113, 104381. [CrossRef] [PubMed]

165. Lee, Y.S.; Dutta, A. MicroRNAs in Cancer. Annu. Rev. Pathol. 2009, 4, 199-227. [CrossRef] [PubMed]

166. Saliminejad, K.; Khorram Khorshid, H.R.; Ghaffari, S.H. Why Have MicroRNA Biomarkers Not Been Translated from Bench to Clinic? Future Oncol. 2019, 15, 801-803. [CrossRef]

167. Kaudewitz, D.; Zampetaki, A.; Mayr, M. MicroRNA Biomarkers for Coronary Artery Disease? Curr. Atheroscler. Rep. 2015, 17, 70. [CrossRef]

168. Snow, O.; Lallous, N.; Singh, K.; Lack, N.; Rennie, P.; Cherkasov, A. Androgen Receptor Plasticity and Its Implications for Prostate Cancer Therapy. Cancer Treat. Rev. 2019, 81, 101871. [CrossRef]

169. Munkley, J.; Vodak, D.; Livermore, K.E.; James, K.; Wilson, B.T.; Knight, B.; Mccullagh, P.; Mcgrath, J.; Crundwell, M.; Harries, L.W.; et al. Glycosylation Is an Androgen-Regulated Process Essential for Prostate Cancer Cell Viability. EBioMedicine 2016, 8, 103-116. [CrossRef] 
170. Kunnumakkara, A.B.; Bordoloi, D.; Padmavathi, G.; Monisha, J.; Roy, N.K.; Prasad, S.; Aggarwal, B.B. Curcumin, the Golden Nutraceutical: Multitargeting for Multiple Chronic Diseases. Br. J. Pharmacol. 2017, 174, 1325-1348. [CrossRef]

171. Lodi, A.; Saha, A.; Lu, X.; Wang, B.; Sentandreu, E.; Collins, M.; Kolonin, M.G.; DiGiovanni, J.; Tiziani, S. Combinatorial Treatment with Natural Compounds in Prostate Cancer Inhibits Prostate Tumor Growth and Leads to Key Modulations of Cancer Cell Metabolism. NPJ Precis. Oncol. 2017, 1, 18. [CrossRef]

172. Javed, Z.; Khan, K.; Rasheed, A.; Sadia, H.; Shahwani, M.N.; Irshad, A.; Raza, S.; Salehi, B.; Sharifi-Rad, J.; Suleria, H.A.R.; et al. Targeting Androgen Receptor Signaling with MicroRNAs and Curcumin: A Promising Therapeutic Approach for Prostate Cancer Prevention and Intervention. Cancer Cell Int. 2021, 21, 77. [CrossRef]

173. Fletcher, C.E.; Sulpice, E.; Combe, S.; Shibakawa, A.; Leach, D.A.; Hamilton, M.P.; Chrysostomou, S.L.; Sharp, A.; Welti, J.; Yuan, W.; et al. Androgen Receptor-Modulatory MicroRNAs Provide Insight into Therapy Resistance and Therapeutic Targets in Advanced Prostate Cancer. Oncogene 2019, 38, 5700-5724. [CrossRef]

174. Lin, P.-C.; Chiu, Y.-L.; Banerjee, S.; Park, K.; Mosquera, J.M.; Giannopoulou, E.; Alves, P.; Tewari, A.K.; Gerstein, M.B.; Beltran, H.; et al. Epigenetic Repression of MiR-31 Disrupts Androgen Receptor Homeostasis and Contributes to Prostate Cancer Progression. Cancer Res. 2013, 73, 1232-1244. [CrossRef]

175. Zheng, L.; Kang, Y.; Zhang, L.; Zou, W. MiR-133a-5p Inhibits Androgen Receptor (AR)-Induced Proliferation in Prostate Cancer Cells via Targeting FUsed in Sarcoma (FUS) and AR. Cancer Biol. Ther. 2020, 21, 34-42. [CrossRef]

176. Lyu, S.; Yu, Q.; Ying, G.; Wang, S.; Wang, Y.; Zhang, J.; Niu, Y. Androgen Receptor Decreases CMYC and KRAS Expression by Upregulating Let-7a Expression in ER-, PR-, AR+ Breast Cancer. Int. J. Oncol. 2014, 44, 229-237. [CrossRef]

177. Bao, S.; Jin, S.; Wang, C.; Tu, P.; Hu, K.; Lu, J. Androgen Receptor Suppresses Vasculogenic Mimicry in Hepatocellular Carcinoma via CircRNA7/MiRNA7-5p/VE-Cadherin/Notch4 Signalling. J. Cell. Mol. Med. 2020, 24, 14110-14120. [CrossRef] 